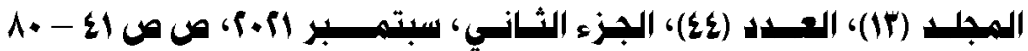

دور الوالدين في تنمية اللغة التعبيرية عند الاطفال ضعاف السمع

$$
\text { ! }
$$

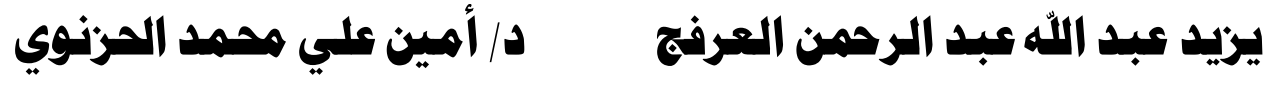

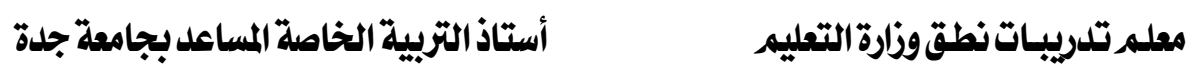




\section{لدور الواللين في تنمية اللنة التعبيرية عند الاطفال ضعاف السمح إن}

يزيل عبد الله عبل الرحمن العرفج (*) \& د/ أمين علي محمد الحزنوي (*)

\section{هli}

هدفت هذه الدراسة الى معرفة دور الوالدين في تتمية اللغة التعبيرية عند الأطفال ضعاف

السمع، وسعت أيضاً الى الكثف عن أثر متغيرات الدراسة (المستوى التعليمي لأحد للوالدين، جنس الطفل ضـعيف السـع، المرحلـة الدراسـية للطفل ضـعيف السـع، درجـة الفقدان السـعي للطفل) وتأثيرها على دور الوالدين في تتمية اللغة التعبيرية عند الأطفال ضعاف السمع. ولتحقيق أهداف الدراسـة، استخدم الباحثان المـهـج الوصـي التحليلي، وتكون مجتمـع الدراسـة مـن أسـر الأطفـال ضعاف السمع المتواجدون في المدارس والمراكز والمعاهد الحكومية الملحقة بفصول ضعاف السمع التابعـة لـوزارة التعليم في المملكـة العربيـة السـعودية. وتمثلت عينـة الدراسـة في العينـة العشـوائية البسيطة من أسر الأطفال ضعاف السمع الذي بلغ عددهم ( • ب) أسرة.

توصلت الدراسة الى مجموعة من النتائج؛ أبرزها: أن أفراد عينة الدراسة موافقون على دور الوالدين في تتمية اللغة العربية عند الاطفال ضعاف السمع حيث بلغ الوزن النسبي لدرجة موافتتهم (\% \% ( ) وجاء في المرتبة الأولى العوامل النفسية المرتبطة بوالدي ضعيف السمع والتي تؤثر على لغته التعبيريـة بنسبة (ع \% \% \%)، ثم العوامل الثقافية المرتبطة بوالدي ضعيف السمع والتي تؤثر على لغته التعبيرية بنسبة (\% \% \% ( ) ثم العوامل الاجتماعية المرتبطة بوالدي ضعيف السمع

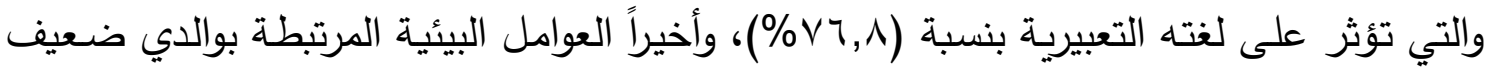
السمع والتي تؤثر على لغته التعبيرية بنسبة ( Y \% \% ).

الكلمات المفتاحية: دور الوالدين، تنمية، اللغة التعبيرية، الاطفال، ضعاف السمع.

E-mail: yazeed.alarfaj@gmail.com معلم تدريبات نطق - وزارة التعليم. (*) (**) أستاذ التربية الخاصة المساعد بجامعة جدة: E-mail: aalhaznawi@uj.edu.sa 


\title{
The role of parents in the development of expressive language for children with hearing impairment $\square$
}

\author{
By \\ Mr.Yazeed Abdullah Alarfaj ${ }^{(*)}$ \&Dr. Ameen Ali Alhaznawi ${ }^{(* *)}$
}

\section{Abstract}

This study aimed to know the role of parents in the development of expressive language in children with hearing impairments and sought to reveal the effect of the study variables (Education level of one of the parents, the school stage of the hearing-impaired child, the gender of the hearing-impaired child, the degree of hearing loss of the hearing-impaired child) on the role of parents in Expressive language development in hard of hearing children. To achieve the objectives of the study, the researchers used the descriptive analytical method, and the study population consisted of families of hearing-impaired children who are present in schools, government centers and institutes attached to the hearing-impaired classes of the Ministry of Education in the Kingdom of Saudi Arabia. The sample of the study consisted of a simple random sample of the families of children with hearing impairment, which numbered (390) families.

The study reached a set of results: the most prominent of which is that the study sample members agree on the role of parents in developing expressive language for children with hearing disabilities as the relative weight of the degree of their approval reached (77.6\%), in the first place came the psychological factors accompanying the parents who suffer from hearing impairment which affects his expressive language at a rate $(79.4 \%)$, then the cultural factors associated with my hearing impaired parents which affect his expressive language at a rate (77.8\%), then the social factors associated with my hearing impaired parents that affect his language Expression (76.8\%), and finally the environmental factors associated with my hearing-impaired father that affect his expressive language (76.2\%).

Keywords: the role of parents, development, expressive language, children, the hard of hearing. 


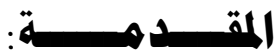

ميزز الله سـبحانه وتعـالى بنـي البشـر عـن سـائر المخلوقـات باللغــة المنطوقـة فهـي أداة تواصلهم، ومصدر قوتهم وتفردهم (حسين، 10 • ب). ويعد الاهتهام بالفئات ذوي الاحتياجـات

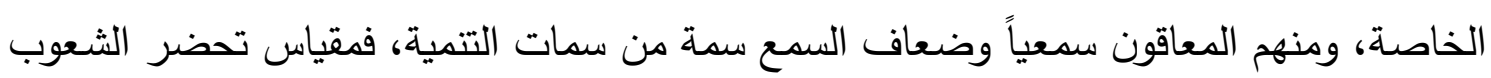

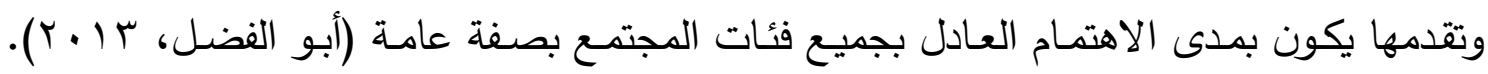
ويعد الإنسان بطبعه كائناً اجتماعياً ينشأ في جماعة، وينتمي إليها ويتفاعل مع أعضائها، ويتواصل

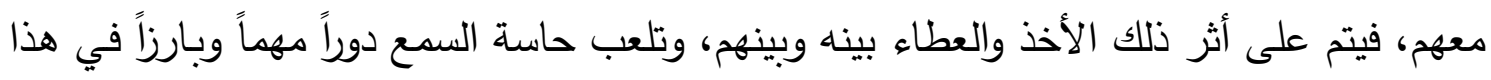

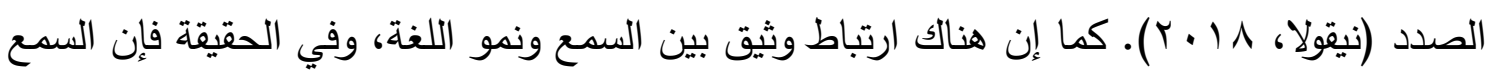
الطبيعي ضـروري لنمو اللغة المنطوقة أو اللفظية، والطفل الذي لا يسمع اللغة من حوله يواجـه صعوبة في تعلمها، ولذلك فإن أحد أسباب اضطرابات اللغة لاى الأطفال هي الإعاقة السمعية،

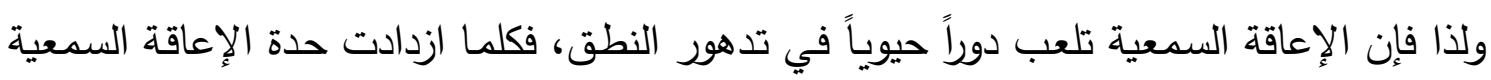
كلما كانت مشكلات النطق المصاحبة أكبر وأعمق، أي أن العلاقة بينهما علاقة طردية فكلما زادت حدة الفقد السمعي زادت معها مشكلات النطق (حسين، 10 • ب). ويعتبر النمو اللغوي أكثر المظاهر تأثراً بالإعاقة السمعية؛ فالعلاقة بينهما طردية، والإعاقة تلقي بظلالها على جميع جوانب النمو اللغوي، والطفل ذو الفقدان السمعي يفتقر الى اللغة بسبب عدم توفر تغذية راجعة سمعية، فهو لا يتلقى أي رد فعل سمعي ولا يتلقى تعزيزاً لفظياً عند إصدار الأصوات، وكذلك لا يسمع نماذج كلامية لتقليدها فكلامهه يتصف بالبطه، وجمله تتميز بالقصر والتعقيد، وألفاظـه تدور حول الملموس. ولذلك من الأهمية أن يبدأ والدا الطفل المعوق سمعياً

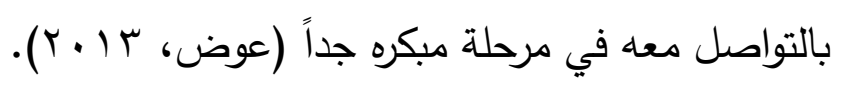

\section{هشكــلة الـــدراســـة}

تتابين المشكلات الناتجـة عن الإصـابة بضـف السمع بـاختلاف العوامل المؤثرة على المظـاهر النمائيـة المختلفة، كمـا أن العـر عند الإصـابة بالإعاقـة السمعية ونوع ودرجـة الفقدان السمعي ومدى إدراك المعاقين سمعيا لفوائد استخدام السماعات الطبية أو التكنولوجيا السمعية في 
الحياة اليومية، وردود فعل الآباء الانفعالية ومستوى تعليم وتأهيل الآباء والبيئة السمعية المحيطة كلها تعتبر من العوامل المؤثرة على حياة الفرد المعاق سمعيا وأنثطته اليومية والتقليل من آثار ضـعف السمع على حياة الطفل ضـعيف السمع وخاصـة على اكتسابه للغـة. ومـن الملاحظ أن بعض الأسر تفتقر التوعية الخاصـة بالضـفف السمعي لدى أطفالهم؛ لذلك يضعوهم في مدراس الأمل للصم والبكم التي تركز على لغة الإثارة فيتعود الطفل ضعيف السمع عليها، والتي تقتل لديه

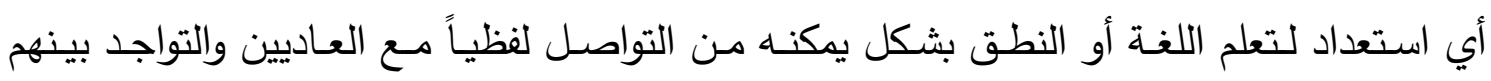
والتفاعل معهم. وقد أشـارت بعض الدراسـات إلى وجود علاقة كبيرة موجبـة بين قدرة الأطفـال ضعاف السمع على إدراك الكلام ومهارات اللغة المنطوقة لديهم. أي أنه لكي يكون للطفل ضعيف السمع لغـة منطوقة لابـد أن يدرك الكـلام من خـلال سماعه باستخدام معينـات سمعية وبرنـامج

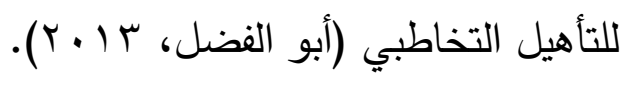

وان دور الوالدين في تتمية اللغة التعبيرية عند طفلهم ضعيف السمع يساهم ويساعد على

تطورها بثكل جيد؛ وذلك من خلال معرفة وإلمام الوالدين بطريقة التواصل المتبعة في تطوير لغة ابنهم التعبيريـة واستخدام الوسـائل والادوات المناسبة، -كمـا يمكن القول - بأن الاسـرة هـي البيئة الأساسية التي يعيش فيها الطفل والتي تؤثر بشكل ملموس عليه، حيث انه يعاني العديد من الاطفال ضعاف السمع من قلة تقدير الوالدين لمشكلتهم، ويعتبر الوالدين هم المعلم الأساسي لطفلهم ضعيف السمع ومنهم يكتسب الاستماع، واللغة، من خلال نثاطات الحياة اليومية، وليس بإمكان المعلم وحده ان ينمي لغة الطفل ضعيف السمع بمعزل عن الاسرة، مما يشير الى ان الاطفال ضـعاف السمع بحاجة الى من ينمي لغتهم التعبيرية بمشاركة الوالدين لنجاح عملية وتطور اللغة التعبيرية لديهم.

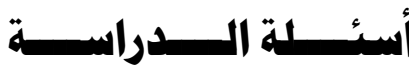

1- ما هو دور الوالدين في تتمية اللغة التعبيرية عند الاطفال ضعاف السمح؟ r- ما مدى الاختلاف في استجابات الوالدين حول دورهم في تتمية اللغة التعبيرية عند الطفل ضعيف السمع تبعاً إلى المستوى التعليمي لأحد الوالدين (اقل من الثانوية العامـة، ثانوي، دبلوم، جامعي، دراسات عليا)؟ 
ب- ما مدى الاختلاف في استجابات الوالدين حول دورهم في تتمية اللغة التعبيريـة عند الطفل

$$
\text { ضعيف السمع تبعاً إلى جنس الطفل ضعيف السمع (ذكر أو أنثى)؟ }
$$

ع - ما مدى الاختلاف في استجابات الوالدين حول دورهم في تتمية اللغة التعبيريـة عند الطفل

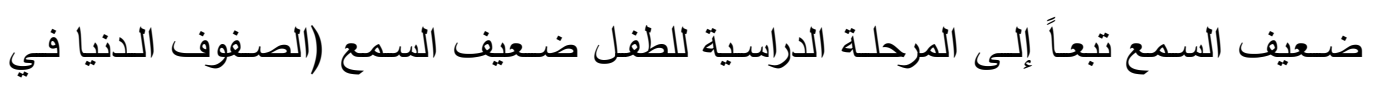

$$
\text { المرحلة الابتدائية، الصفوف العليا في المرحلة الابتدائية)؟ }
$$

ه- ما مدى الاختلاف في استجابات الوالدين حول دورهم في تنمية اللغة التعبيريـة عند الطفل

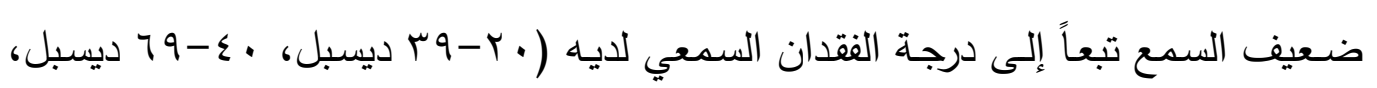

$$
9 \cdot-V \text {. }
$$

\section{أهـــداف الــدراسـسة}

ا- التعرف على دور الوالدين في تنمية اللغة التعبيرية عند الأطفال ضعاف السمع. ץ- التعرف على مدى اختلاف استجابات الوالدين حول دورهم في تنمية اللغة التعبيريـة عند الطفل ضـعيف السمع تبعاً إلى المستوى التعليمي لأحد الوالدين (اقل من الثانويـة العامـة، ثانوي، دبلوم، جامعي، دراسات عليا). ب- التعرف على مدى اختلاف استجابات الوالدين حول دورهم في تتمية اللغة التعبيريـة عند الطفل ضعيف السمع تبعاً إلى جنس الطفل ضعيف السمع (ذكر أو أنثى). ع - التعرف على مدى اختلاف استجابات الوالدين حول دورهم في تتميـة اللغـة التعبيريـة عند الطفل ضعيف السمع تبعاً إلى المرحلة الدراسية للطفل ضعيف السمع (الصفوف الدنيا في المرحلة الابتدائية، الصفوف العليا في المرحلة الابتدائية). 0- التعرف على مدى اختلاف استجابات الوالدين حول دورهم في تتمية اللغة التعبيريـة عند الطفل ضـعيف السمع تبعـاً إلى درجة الفقدان السمعي لديـ ( • ب-9 ب ديسبل، • ع-9

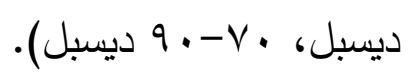

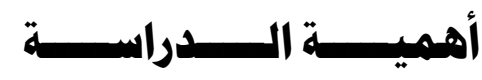

تتبع اهمية الدراسة في كونها تتاقش موضوعاً هاماً في الميدان التعليمي؛ وهو دور الوالدين في تتمية اللغة التعبيرية عند الاطفال ضعاف السمع، ومن اهم الجوانب التي تبرز فيها اهمية هذه الدراسة: 
1- قلة وعي الوالدين في تنمية اللغة التعبيرية عند الطفل ضعيف السمع. r-ابراز اهمية دور الوالدين في تتمية اللغة التعبيرية عند الطفل ضعيف السمع. r- اهمية اللغة التعبيرية ودورها المساهم في كافة مجالات الحياة عند الطفل ضعيف السمع.

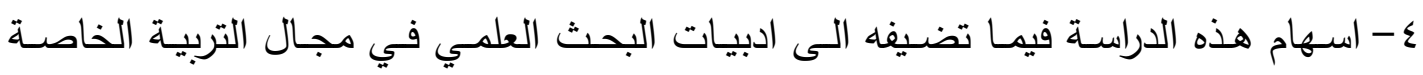

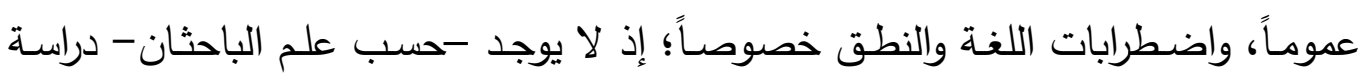

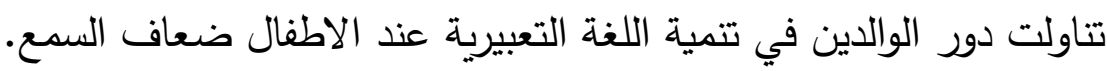

\section{ثانياً: الأهميــة التطبيقيـــة}

1- ان نتائج هذه الدراسة وتوصياتها تساعد في تقديم معلومات الى المعلمين ووالدي الطفل ضعيف السمع حول دور الوالدين في تنمية اللغة التعبيرية عند الاطفال ضعاف السمع. r-تحديد ماهية دور الوالدين تجاه طفلهم ضعيف السمع؛ وتعد هذه الدراسة إجراء وقائيا تربوياً يتيح التعرف على دور الوالدين في تتمية اللغة التعبيرية عند الاطفال ضعاف السمع، ومن لون ثم معرفة الدور الفعال الذي يقوم به الوالدين تجاه الطفل ضعيف السمع، بالإضـافة الى بلى طريقة تتمية اللغة التعبيرية لدى طفلهم ضعيف السمع بشكل صحيح.

\section{هصطاتسـات الــدراســة}

\section{The Role of Parents دور الــوالــديـن}

مجموعة من الأفعال التي يقوم بها الوالدين داخل الأسرة تجاه الأبناء في المواقف الحياتية

$$
\text { المختلفة لمواجهة التغيرات التي تحدث بالمجتمع (الحازمي، } 9 \text { ( ـ ب). }
$$

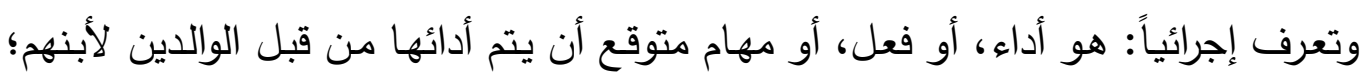
وذلك بغرض تقديم المساعدة التي يحتاجها في كافة احتياجاته المختلفة.

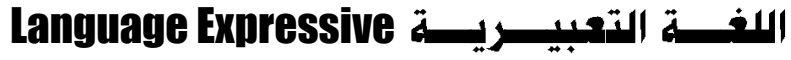

هي قدرة الطفل على التحدث والتعبير الثفوي الواضح والسليم من حيث المعنى والنطق والطلاقة والتركيب وطول الجملة، والاستخدام اللفظي السليم والصحيح لجميع مكونات اللغة من

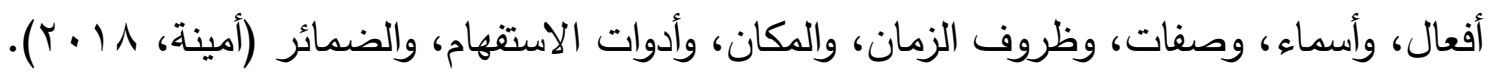


وتعرف إجرائياً: هي استخدام اللغة وتوظيفها من خلال عملية الكلام، والتي من خلالها يعبر الفرد عن آرائه، وأفكاره، ومشاعره، واحتياجاته والتي من خلالها يتواصل مع الآخرين ويتفاعل معهم في مجتمعه.

\section{Hearing Impaired}

هم الأطفال الذين يفقدون حاسة السمع بشكل كلي او جزئي؛ ويؤدي ذلك الى عدم استجابتهح للأصوات العالية، وبالتالي فإنهم يصابون بفقدان سمعي كلي او جزئي في الأذن؛ وهو ناتج عن خلل

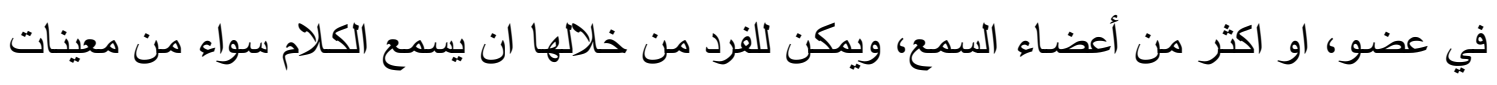
سمعية، او بدونها، ويتدرج من البسيط الى الثديد الى الصمم الكلي (Shangase, 2021).

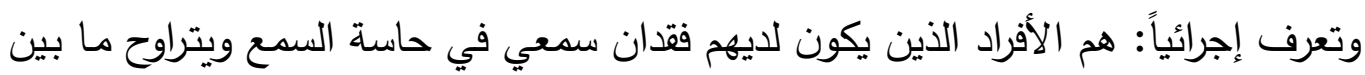

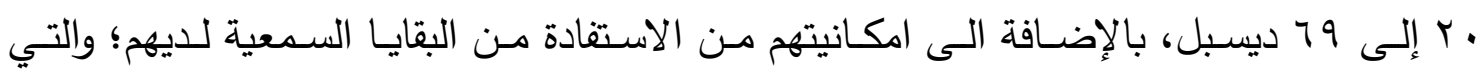
تساعدهم في عملية الاستماع، والتواصل مع الآخرين.

\section{الإطــار النظــري والـدراسـات الســابقــة}

\section{المحور الأول: دور الوالدين في تنمية اللغة التعبيرية}

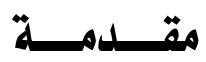

ان دور الأسرة فعال بالنسبة للأطفال المعاقين سمعياً، حيث يواجه الأطفال المعاقين سمعياً العديد من الصعوبات في إقامة علاقات اجتماعية مع الأخرين، فهم يشعرون بالعزلة الاجتماعية

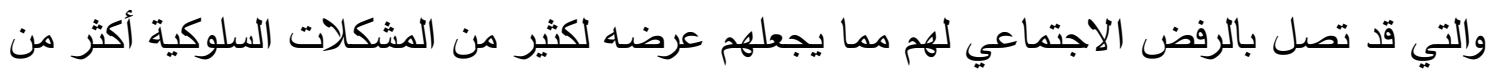
أقرانهم العاديين، وهنا يظهر دور الأسرة في توفير المناخ الاجتماعي الذي يتسم بالألفة والتقبل

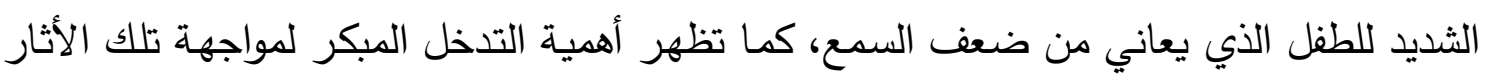

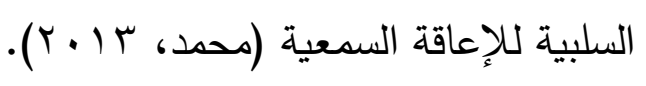

\section{مفهوم الأسرة وعلاقتها المؤثرة في تنمية اللفة التعبيرية}

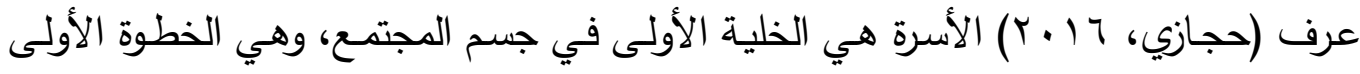
التي يبدأ منها التطور، حيث تعتبر البيئة والمحيط الاجتماعي الذي ينثأ فيه الفرد منذ نعومة أظافره، 
لذلك تعد المكون الأساسي، والعام الذي يقوم عليها المجتمع. وكذلك عرف (محمد، 17 + ب) الأسرة بأنها الجماعة التي الاطار الأول الذي يستقبل الطفل في بداية حياته، وتعمل على الدحافظة عليه في

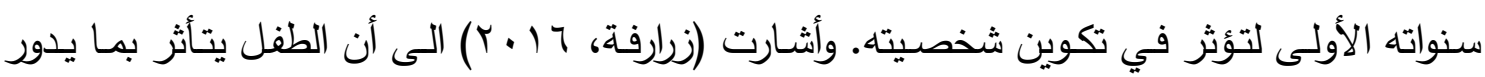

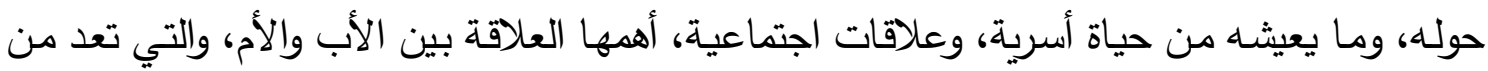

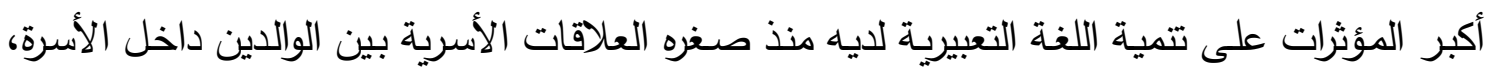
حيث يتأثر الطفل بوجود السعادة الأسرية، ويتأثر أيضا بوجود المشكلات الأسرية والتفكك الأسري.

\section{أنماط تواصل الوالدين في اللغة التعبيريتة مع الأطفال ضعاف السمع.} يعد التواصل اللفظي هو الوسيلة التي يمكن من خلالها إرسال واستقبال اللغة التعبيرية بين التين الطفل والأسرة، ولكن فيما بتعلق بالأطفال ضعاف السمع، فهناك نمطين يمكن من خلالهم التواصل مع هؤلاء الأطفال لتتمية اللغة التعبيرية لديهم، وهم: أ) نمط التواصل الجزئي: وفي هذا النمط من التواصل يستخدم التواصل الثفهي، أو اللفظي حيث يتم الاعتماد على السماعات، ومكبرات الصوت، ومهارة قراءة الثفاء، أو التواصل

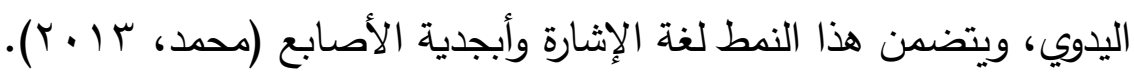
ب) نمط التواصل الكلي: وهي الطريقة الأكثر استخداما، وتتضمن استخدام أنواع متتوعة من طرق التواصل للمسـاعدة على التعبير، واكتســاب اللغـة، ومـن هذه الطـرق: الكـلام، ولغـة الإثارة، والايماءات، والتعبيرات الوجهية والجسية، وقراءة الكلام، وتهجئة الأصـابع. والجدير بالذكر ان التواصل الكلي لا يستخدم مـع الأطفال الصم فقط، بل هو قابل للاستخدام مـع بعض الأشخاص ذوي الإعاقات الأخرى مثل: التوحد، المعوقين سمعياً (تواتي، 9 ( • ؟).

\section{استراتيجيات الوالدين في تنميتة اللغتة التعبيريتة لدي الأطفال ضعاف السمع} 1- استراتيجية التواصل الثفهي: هذه الاستراتيجية تتضمن استخدام السمع المتبقي من خلال التدريب السمعي، وتضخيم الصـوت، وقراءة الشفاه والكـلام، وهذه الاستراتيجية تستخدم الطرق الأتية في التدريب ومنها: التدريب السمعي الثشامل، طريقة وحدات المقاطع المتعدد الحواس، قراءة الثفاه، قراءة الكلام، التدريب على الكلام (الزريقات وشرادقة، ب ( ب). 
ץ- استراتيجية القصة: تعد استراتيجية القصة من أهم الاستراتيجيات التي يعتمد عليه الوالدين

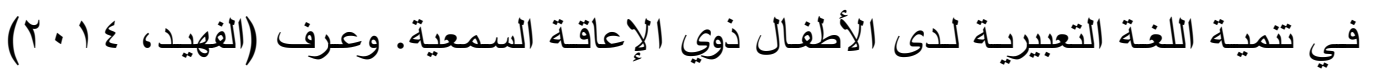
القصـة بأنها: عبارة عن إجراءات تعليمية، ومنظمـة تتمثل في العرض السردي الشفوي، وتكون مصحوبة بالوسائل والصور المعبرة، بالإضـافة الى المثيرات الصوتية، وحركات الجسد بالإضافة عن غيرها من الأنثطة الثفوية والكتابية الدصاحبة للقصة. r- استراتيجية المحاكاة باستخدام الحاسب الألي: تعد استراتيجية المحاكاة من خلال استخدام الحاسب الألي من أهم الاستراتيجيات التي يعتمد عليها الوالدين في تتمية اللغة التعبيريـة

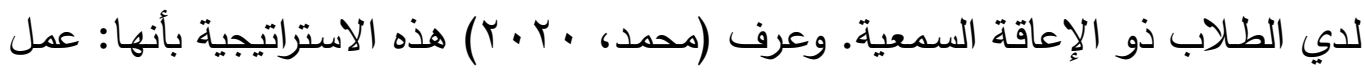
برمجية تقدم للأطفال عبر الحاسب الألي حتي يتيسر عرضها ويستطيع الطفل من خلالها أن يتعلم وفقاً لقدرته ومستوله، ويستطيع أن يعيد تكرار البرنامج اكثر من مرة، ويقوم الطفل بمحاكاتها والتكرار معها وبعدها يقلدها دون ملل. ع - الأنثطة اللفويـة الموسيقية: يمكن للوالدين الاعتماد على الأنشطة الموسيقية في تتمية اللغة التعبيرية لاى الأطفال، حيث يمكن من خلال الأنثطة الموسيقية تشجيع الطفل كي يستخدم اللغة، والكلمات المختلفة، وتحسين التواصل اللفظي، وهو الأمر الذي يساعد على لئ إكساب الطفل العديد من المهارات اللفظية كنطق الكلمات والجمل (مصطفى، 17 ( ب). ه- استراتيجية التواصل اليدوي: ونجد ان التواصل اليدوي يتعدد على استخدام رموز يدوية

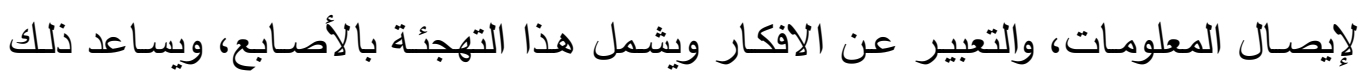
على وصول ايماءات لضعاف السمع على وجود بعض الحركات التي تعبر عن مواقف معينة (Bin Saddiq, 2021).

4- استراتيجية التواصل الكلي: وهي التي تعطي عناية بالكلام، واستغلال البقايا السمعية؛ باستخدام الاجهزة السمعية مع لغة الاشارة في نفس الوقت، وتستخدم هذه الاستراتيجية مع جميع الاطفال ضعاف السمع حيث أثثت انها لا تهيث المهارات الشفهية، وبالتالي يكون هناك تحسن ملحوظ في اللغة التعبيرية لديهم (Hettiarachchi, 2020). 


\section{المحور الثاني: اللفة التعبيرية عند الأطفال ضعاف السمع}

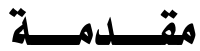

تعد اللغة من أهم الأدوات التي لها دور حيوي في حياة الأفراد في المجتمع، حيث يعتمد عليها الفرد في التواصـل والتفاعل مـع الأخرين، وقد أمرنـا الله تعـالي بـالحفظ للغـة العربية بقولهـ تعالى: (إن نحن نزلنا الذكر وإنا له لحافظون)، ومن هنا يجب علينا الحفاظ على اللغة لكي يمكن التواصـل بـين أفراد المجتمع بسـهولة، وتعـد اللغـة التعبيريـة عند ضـعاف السـمع هـي الأداة التي يعتمدون عليها في التعبير عن أفكارهم و أراءهم، وتشير اللغة التعبيرية الى إصدار الرموز اللغويـة في صورة كلامية حركية من خلال قدرة الفرد على التعبير عن أفكاره بكلمات منطوقة، أو مكتوبـة على أن تكون الكلمات واضحة ومفهومة للمتلقي (سعدي، 1 ( • ).

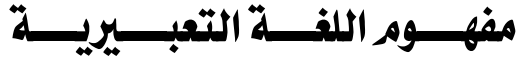

عرف (الكفوري، · ب · r) اللغة التعبيريـة بأنها: ما ينحرف عن الكلام العادي ويستخدمها الطفل عندما يكون كلامـه العـادي غير واف أو محقق للغرض، فيبتكر لغـة تكنيكية جديدة ذات رطآئه خاصة به يصحبها للتعبير عن المعني المحدود لديه والذي يتوافق مع درجة تفكيره. وكذلك عرف (محمود، 1 1 • r) اللغة التعبيرية بأنها: إصدار الرموز اللغوية في صورة كلامية حركية، من خلال تجزئة اللغة التعبيرية الى مكونات لها صلة، بحيث القصور في إحداها يؤدي إلى مشكلات في عملية التواصل، فهي مجموعـة من المهارات المسئولة عن تحويل الأفكار الى رموز لغويـة صوتية، فالرسالة تكون لفظية وتتحول إلى ردوز صورية بصرية يمكن من خلالها أن يفهم المتلقي ما يريد الطفل ذو الإعاقة السمعية أن يقوله للمتلقي. وعرف (Caselli et al, 2021) اللغـة التعبيريـة بأنها: الوسيلة والنشـاط الاجتمـاعي الذي يمكن لضعاف السمع مـن خلالـه التعبير عن أنفسه، حيث يكون في مقدرة الطفل التعبير عن الأفكار، والاحتياجات، والرغبات، حيث يعد تمييز الكائنات الحية في البيئة ووصف الاحداث، والإجراءات ،والاجابة على الأسئلة وتقديم الطلبات من امثلة مهارات اللغـة التعبيريـة، حيث ان اللغـة التعبيريـة لا تحتوي فقط على استخدام اللغـة بشكل مناسب، ولكنها تتضمن تعبيرات الوجه والايماءات. 


\section{تشخيص اللختة التعبيريتة}

ان الهـدف مـن التشـخيص هـو تحديــ طبيعـة اضـطراب التواصـل، ومعرفـة مـدى قابليتهـه للعلاج، ويتطلب ذلك دراسـة حالة الطفل التي يجب ان تحتوي على المظاهر النمائيـة والتطوريـة للى الطفل. كما ان مرحلة قياس وتشخيص للاضطرابات اللغوية تمر بعدة مراحل وهي كما يلي: المرحلة الأوله: مرحلة التعرف المبدئي على الأطفال ذوي المشاكل اللغوية: وفي هذه المرحلة يلاحظ الآباء والأمهات، والمعلمون والمعلمات، مظاهر النمو اللغوي، وخاصة مدى استقبال الطفل للغة، وزمن ظهورها والتعبير بواسطتها والمظاهر غير العادية للنمو اللغوي. المرحلة الثانبـة: مرحلة الاختبار الطبي الفسيولوجي للأطفال ذوي المشكلات اللغويـة: وفي هذه المرحلة وبعد تحويل الأطفال ذوي المشكلات اللغوية، أو الذين يشك بـأنهم يعانون من اضطرابات لغوية، إلى الأطباء ذوي الاختصاص. المرحلة الثالثة: مرحلة اختبار القدرات الأخرى ذات الصلة للأطفال ذوي المشكلات اللغويـة: وفي هذه المرحلة وبعد التأكد من خلو الأطفال ذوي المشكلات اللغوية من الاضطرابات العضوية، يتم تحويل هؤلاء الأطفال الحى ذوي الاختصـاص في الإعاقـة العقلية، والسمعية، والثلل الدماغي، وصعوبات التعلم، وذلك للتأكد من سلامة أو إصـابة

$$
\text { الطفل بإحدى الإعاقات التي ذكرت سابقاً. }
$$

المرحلة الرابـهة: مرحلة تشخيص مظاهر الاضطرابات اللغويـة للأطفال ذوي المشكلات اللغويـة: وفي هذه المرحلة وفي ضوء نتائج المرحلة السـابقة، يحدد الأخصـائي في قياس وتشـخيص الاضطرابات اللغويـة مظـاهر الاضـطرابات اللغويـة التي يعـاني منهـا

$$
\text { الطفل (عرعار وهاشمي، } 17 \text { ( • (؟). }
$$

\section{أسباب اضطراب اللغتة التعبيريتة}

إن اسباب اضطراب اللغة التعبيرية التي تحدث للأطفال ضعاف السمع نتيجة مجموعة من الأسباب منها ما يتعلق بالطفل، ومنها ما يتعلق بالأسرة، والبيئة، ومنها ما يتعلق بالفقدان السمعي، وهناك ايضاً الأسباب العضوية وسنفصلها كما يلي:

1- الأسباب المتعلقة بالطفل: تتمثل هذه الأسباب في: تاريخ اكتشاف الضعف السمعي، درجة القصـور السـمعي ومـدى تغيرهـا، عـدم قدرة الطفـل المعـاق سـعياً على تقليد أصـوات 
الآخرين؛ نتيجة لضعف سمعه، وجود خلل في الأجهزة المسئولة عن الكلام والنطق للى

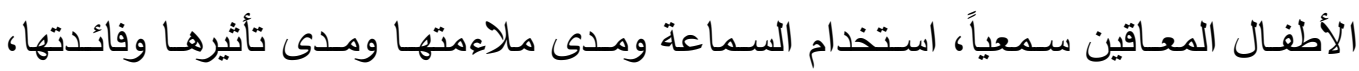
الإصابة بإعاقات أخرى غير ضعف السمع، القدرة العقلية لدى الطفل ضعيف السمع. r- الأسباب المتعقة بالأسرة والبيئة: وتتمثل هذه الأسباب في اتجاه الوالدين نحو إعاقة الطفل وتأثرهما بها، المستوى الاقتصادي والاجتماعي والثقافي للأسرة، تكرار حالات الإعاقة السمعية في الأسرة، عدم مشاركة الوالدين في برامج التأهيل اللغوي لأطفالهم المعاقين سمعياً، نوع وحجم المدرسة الملتحق بها الطفل ضعيف السمع، إمكانات المدرسة ومدى الاستفادة منها، اهتمـام المعلم او المدرب بالتركيز على إخـراج أصـوات الحروف، وإهمـال الجانب المعرفي والاشتقاقي للكلمة؛ وذلك سبب ضعف الحصيلة اللغوية عند المعاقين سمعياً نتيجة لما يستغرقه التدريب الصوتي من زمن يطغى على حاجة الدعاق سمعياً للفهم والإدرالك (السيد، 10 • ب). r- الأسباب المتعقة بالفقدان السمعي: من اهم الاسباب التي تؤدي الى اضطراب اللغة هو نوع الفقد السمعي، ونجد ان درجة الفقد تؤثر حيث ان الاطفال الذين لديهم ضعف سمع بدرجة قليلة يعانون في اضطراب اللغة بدرجة قليلة عن الذين يعانون من فقدان السمع بدرجة كبيرة.

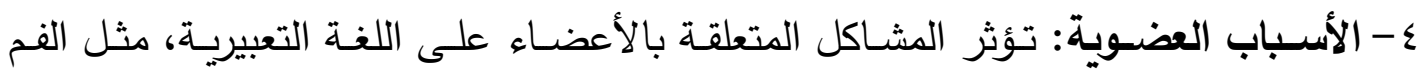
المشقوق؛ والذي يرجع الى عيوب تكوينية نتيجة عدم التئام العظام او الأنسجة، كما توجد مشاكل عضوية اخرى تتعلق باللسان، والتي تؤدي الى قلة استخدام المكونات المورفولوجية للغة، والاستخدام المحدود لتراكيب الجملة، ويظهر أصحاب الحنك المشقوق أصواتاً أنفية مرتفعة، وعيوب نطق مميزة إلى حد ما بالرغم من أنـه في بعض الثقوق الصغيرة، أو الشقوق المعالجة ربما لا تؤدي الى وجود مشكلات في النطق (Caselli et al, 2021).

\section{المحور الثالث: اللفة التعبيرية عند الأطفال ضعاف السمع}

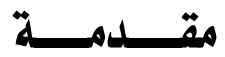

لقد أنعم الله سبحانه وتعالى على الإنسان بمجموعة من الحواس، كي يستطيع من خلالها الحصول على كل ما يحتاج من معلومات عن عالمه الخارجي، وتعتبر حاسة السمع من أهم هذه 
الحواس؛ وتعود هذه الأهمية في أنها تسمح للفرد في المشاركة الايجابية في عملية اكتساب اللغة، التي تعد من اكثر أشكال الاتصال والتفاهم سهولة وشيوعاً وسيادة بين الناس (صالح، ـ ( ب).

\section{مفهـــوه الاطفــال ضعــاف السمـــع}

عرف (عاشور والثهراني، 9 ( ب) الطفل ضعيف السمع بأنه هو: الطفل الذي فقد حاسة السمع بصورة جزئية، ولديه بقايا سمعية تؤهله في التواصل مع الآخرين، سواء باستخدام المعينات

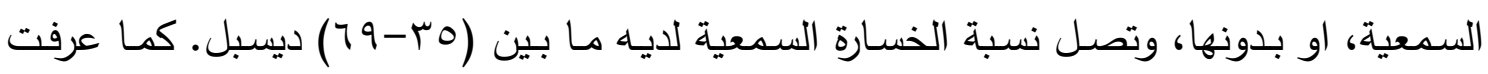

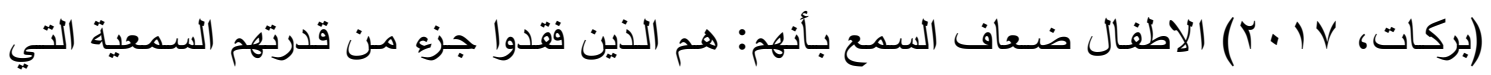
تحول دون اكتساب اللغة والكلام بوضسوح من الآخرين، ويتم تثخيصهم على انهم يعانون من ضعف سمعي بناء على ادوات التثخيص المتوفرة في تلك المدراس، ويتراوح الفقد السمعي ما بين

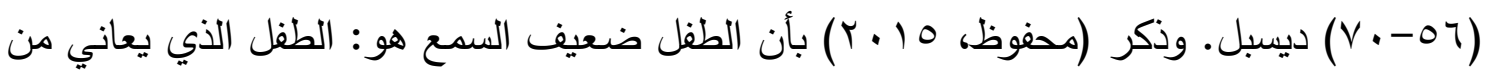
انخفاض في درجات السمع لدرجـة (البسيط، المتوسط)، تستدعي تقديم خدمات لغويـة وتعليمية خاصـة لهم تختلف عن الاطفال العاديين كالتدريبات السمعية. وعرف (ابراهيم، 0 ـ ب ب) الطفل ضعيف السمع بأنه هو: ذلك الثخص الذي لديه بقايا سمعية من خلال معينات سمعية خاصـة تجعله قادر على تمييز المعلومات اللغوية.

\section{تصنيف الاطفال ضعاف السمع}

صُنف الأطفال ضعاف السمع الى العديد من التصنيفات وهي كما يلي: اولاً: التصنيف حسب طبيعة موقع الإصـابة: ويعتمد هذا التصنيف على موقع الاصـابة، والجزء المصاب من الجهاز السمعي، ويندرج تحته اربع فئات وهم:

أ) الفقدان السمعي التوصيلي: ينتج من خلل في الاذن الخارجية والوسطى يحول دون نقل الموجات الصوتية الى الأذن الداخلية، مما يؤدي بالفرد الى صعوبة في سماع الاصوات

$$
\text { التي تزيد عن • 7 ديسبل. }
$$

ب) الفقدان السمعي الحسي عصبي: ينتج من خلل في الاذن الداخلية، او العصب السمعي لمدي وعادة فإن درجة الفقدان السمي في هذا النوع تزيد عن • V ديسبل. 
ج) الفقدان السمعي المختلط: ويتمثل في معاناة الثخص من فقدان سمعي توصيلي وفقدان

$$
\text { سمعي عصبي في نفس الوقت. }
$$

د) الفقدان السمعي المركزي: ينتج من خلل في الممرات السمعية في جذع الدماغ، او المراكز

السمعية يحول دون تحويل الصوت من جذع الدماغ الى المنطقة السمعية في الدماغ.

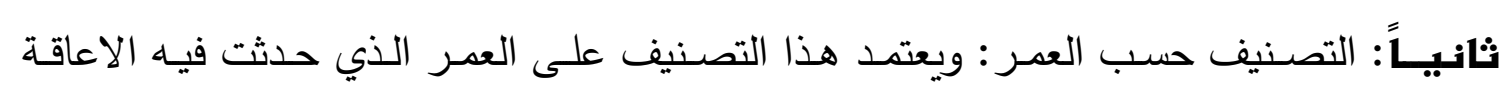

$$
\text { السمعية، ويندرج تحته فئتين وهم: }
$$

أ) صمم مـا قبل اللغة: وهو حدوث الاعاقة السمعية في عمر مبكر وقبل ان يكتسب اللغة

$$
\text { سواء كانت الاعاقة السمعية عند الولادة او مكتسبة. }
$$

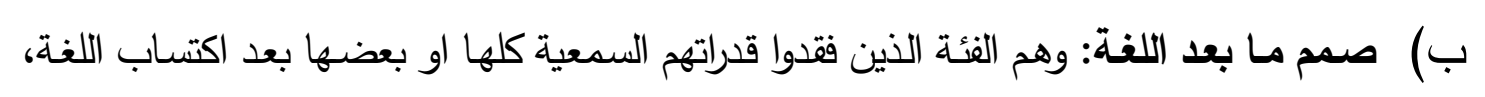
وتتميز هذه الفئة بقدراتها على الكلام لأنها سمعت وتعلت اللغة ويطلق عليها الصمم فقط. ثالثاً: التصنيف حسب شدة الفقدان السمعي: تصنف مستويات الاعاقة السمعية حسب شدة

$$
\text { الفقدان السمعي الى خمس فئات وهي كالتالي: }
$$

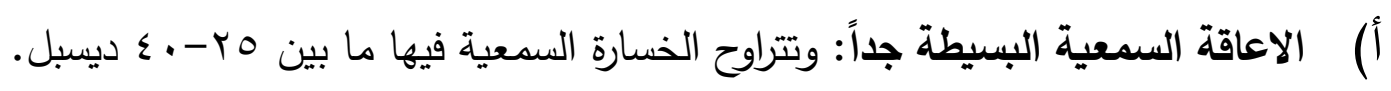

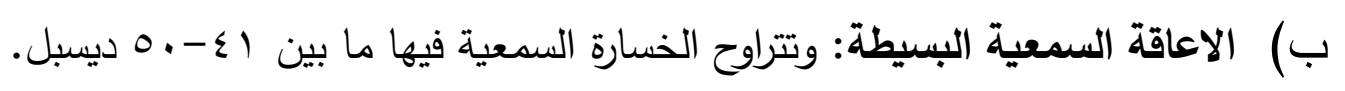



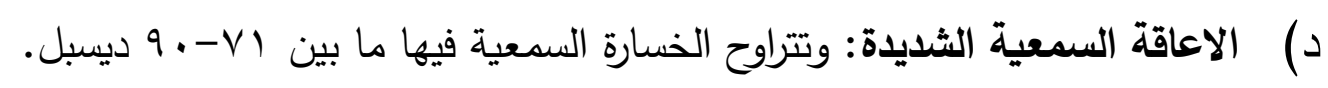
هـ) الاعاقة السمعية الثديدة جداً: وتتراوح الخسارة السمعية فيها أكثر من بو ديسبل (عاشور

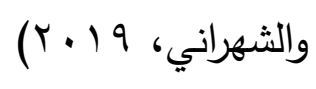

\section{خصسائص الاطفـال ضعـاف السمـع}

توجد مجموعة من الخصائص العامة للأطفال ضعاف السئ السمع وهي:

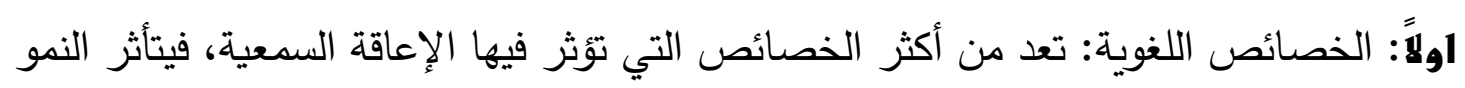

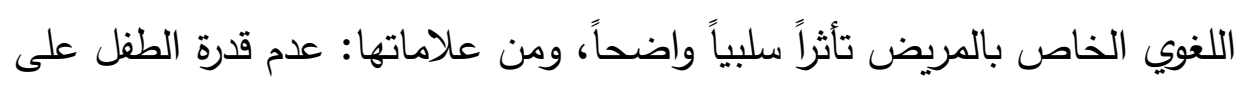

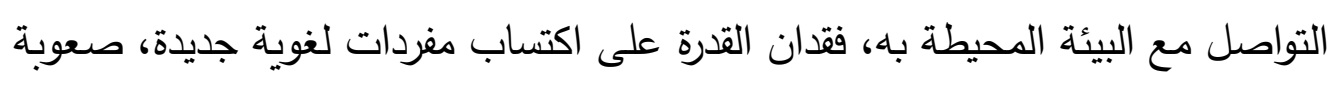
في تركيب الكلمات معاً للحصول على جمل مفيدة. 
ثانياً: الخصائص المعرفية: تثير الدراسات والاختبارات التي تم إعدادها لمتابعة الحالة المرضية للمعاقين سمعيّاً إلى أن قدراتهم المعرفية لا تختلف عن قدرات الأفراد العاديين، بمعنى أن الطفل الذين يعاني من فقدان السمع يمتلك مستوى من الذكاء يتناسب مع مرحلته العمريّة،

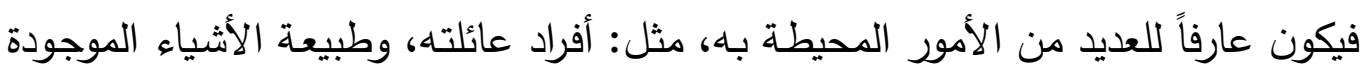
حوله، وأيضـاً يتميز بقدرته على التعلم، وفهم بعض المهارات العمليّة، ولكنه يفقد القدرة على فهم أغلب المهارات اللغوية العادية. ثالثاً: الخصـائص النفسية: تبين الدراسـات ان الخصـائص النفسية للمعوقين سمعياً ترجع الى تعرضهم لمواقف تتسم بالقسوة والتفرقة واثارة الثـعور بالنقص، والاهمال، والسخرية، او تتسم بالإشفاق والتعبير عن هذا الإشفاق امامهم. رابــــاً: الخصـائص الاجتماعيـة: يقسم الافراد ذوي الاعاقـة السـعية بالاعتمـاد على تفـاعلهم الاجتماعي إلى نوعين وهم: أ) القادرون على التفاعل الاجتماعي: هي الفئة التي تكون الإعاقة السمعية عندهم غير مؤثرة في حالتهم النفسية، والسلوكية فيكونون قادين على التفاعل مع الأفراد المحيطين بهم. ب) غير القـادرين على التفاعل الاجتمـاعي: هي الفئة التي تكون الإعاقة السمعية عندهم في مستويات مرتفعة جداً، وتؤثر سلبياً في حالتهم النفسية، وتجعلهم يميلون إلى العزلة الاجتماعية، والامتتاع عن التقاعل مع البيئة المحيطة بهم بثكل شبه مستمر (خضر ، 17 (ب).

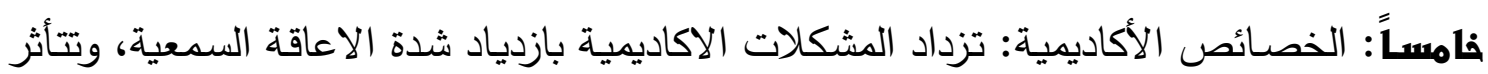
بمدى تأثر القدرات العقلية، والثخصية، والعمر عند حدوث الاعاقة السمعية.

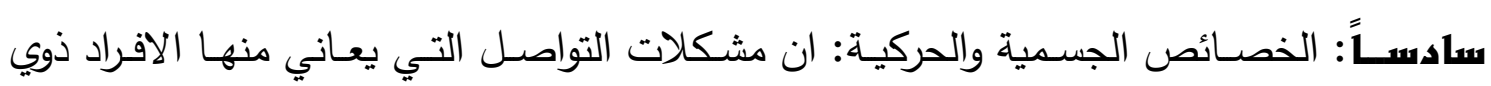
الاعاقة السمعية تضع حواجز وعوائق كبيرة امامهم لاكتثاف البيئة والتفاعل معها، وإذا لم

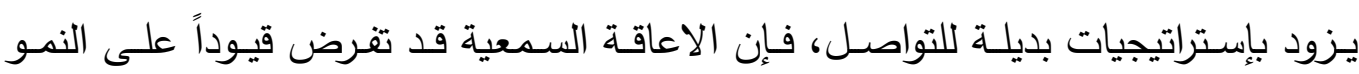
الحركي لديهم، وتكون القيود من خـال حرمان الفرد ذوي الاعاقة السمعية من الحصول

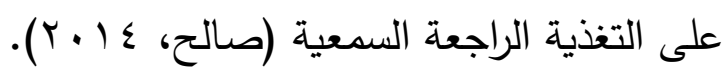




\section{مشكلات اللغتة التعبيريتة لدي الأطفال ضعاف السمع.}

ا- يعـاني الأطفـال ضـعاف السـمع مـن عدم القدرة على اسـتخدام الجمل الطويلـة، حيـث لا يستطيع الطفل مـن استخدام جمل مركبة أو معقدة، خاصـة أن الأطفال ضـعاف السـع يعانون من ضعف في القواعد النحويـة والمفردات اللغويـة، وبالتالي يكون هناك عدم توافق بين الكلام التعبيري والسياق الاجتماعي. ץ- يعاني الأطفال ضعاف السمع من القدرة على استخدام العبارات والكلمات والقواعد اللغويـة الصحيحة، وضعف إدراك السياق الاجتماعي للغة، وضعف القدرة على متابعة الموضوع واختيـار الكلمـات الصـحيحة، الأمـر الذي يـعكس على ضـف المناقشـة لـدي الأطفـال ضعاف السمع. ب- يعـاني الأطفـال ضـعاف الســع مـن ضـعف القدرة على نطـق اللغـة وكتابتها، ومقاومـة المشاركة في الحديث أو الإجابة عن الأسئلة، حيث يقتصر الطفل الذي يعاني من ضعف السمع من اقتصار إجابته على الأسئلة التي توجه إليه، واستخدام أنماط كلامية معينة أثناء الإجابة عن التساؤلات التي توجه إليه من الأخرين، وبالتالي يكون كلام الطفل غير ناضـج

$$
\text { ولا يناسب عمره الزمني (الزريقات وشرادقة، r ا ـ r). }
$$

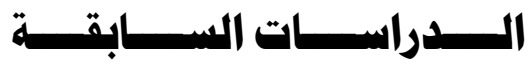

إن الدراسات السابقة مصدر إلهام قوي للباحث مهما كان مجال تخصصـه، فكل بحث يعد امتداد للبحوث السابقة، وتمهيداً للبحوث اللاحقة، وقد اطلع الباحثان على أهم ما جاء في الكتب من أبحاث، ورسائل، ومجلات علمية، حتى يتسنى له رسم خطة موضوعية ومنهجية سليمة تمكنها من الوصول الى تحقيق أغراض الدراسة، وفيما يلي عرض للدراسات التي تيسر للباحث الوصول إليها ومتعلقة بموضوع البحث.

\section{المدور الأول: الدراسات التي تناولت دور الواللين في تنمية اللغة التعبيرية.}

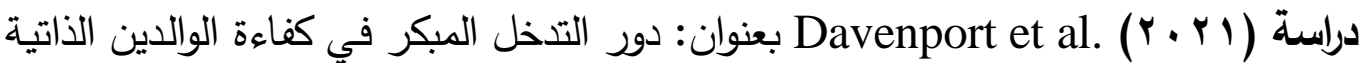
لأولياء أمور الأطفال الصم وضعاف السمع. ولتحقيق أهداف الدراسة اعتمد الباحثون على استخدام 
المنهج الوصفي، وتم استخدام استبانة موجها للوالدين تقيس التخخل المبكر للوالدين من حيث الكفاءة

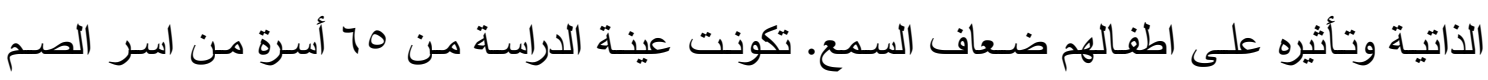
وضعاف السمع. وتوصلت نتائج الدراسة إلى أنه لم يتم العثور على ارتباطات ذات دلالة إحصائية بين العمر في الالتحاق والمقاييس الفرعية، وانهه لم يتم العثور على ارتباطات ذات دلالة إحصائية بناءً على تواتر أو شدة خدمات الذكاء العاطفي. وبينت النتائج المختلطة مستوى مشاركة الوالدين في اتخاذ القرار بشأن أهداف الخطة الفردية لخدمة الأسرة، وأنواع الخدمات، ومقدار الخدمات.

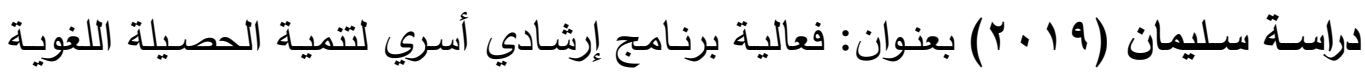
للأطفال ضعاف السمع المعاقين عقلياً. ولتحقيق أهداف الدراسة استخدام الباحث المنهج الوصفي بـاني المسحي من خلال برنامج إرشادي أسري، واختبار استمرارية البرنامج في تتمية الحصيلة اللغوية على المجموعة التجريبية بعد فترة المتابعة. وتكونت عينة الدراسة من (0) أمهات الأطفال ممن بن لديهم إعاقة متعددة (ضعف سمع وإعاقة عقلية) وأطفالهن ممن تتراوح أعمارهم الزمنية ما بين (ه

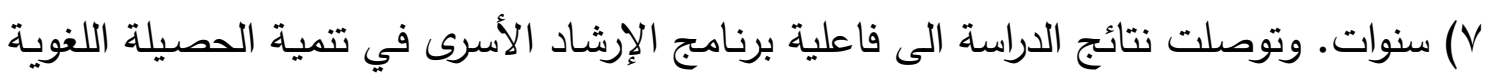
للأطفال ضعاف السمع المعاقين عقلياً.

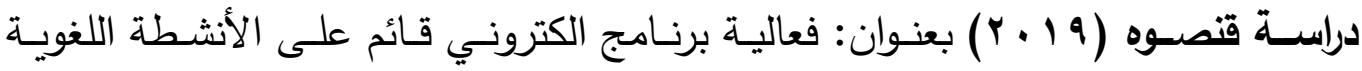
لتحسين اللغة التعبيرية والتواصل الاجتماعي للى ضعاف السمع. ولتحقيق أهداف الدراسة اعتمد الباحث على المنهج الوصفي التحليلي من خلال استخدام مقياس مهارات اللغة التعبيرية لضعاف السمع (إعداد جمال إبراهيم، T/ (ب)، ومقياس التواصل الاجتماعي لضعاف السمع (إعداد: سامي

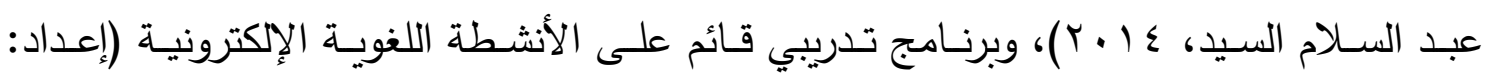
الباحث). وتكونت عينة الدراسة من خمسة أطفال في عمر (ع-7) سنوات من ضـعاف السمع بمتوسط عمري قدره (0,10) عامًا وانحراف معياري قدره (9 r, ·) وتراوحت نسبة فقد السمع لدى

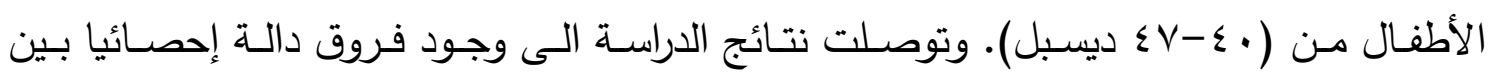
متوسطات رتب درجات أفراد المجموعـة التجريبية في الأداء القبلي والبعدي على مقياس اللغـة التعبيرية لصالح الأداء البعدي، وكذلك وجود فروق دالة إحصائيا بين متوسطات رتب درجات أفراد 
المجموعـة التجريبية في الأداء القبلي والبعدي على مقياس التواصل الاجتهـاعي لصـالح الأداء البعدي، كما تبين عدم وجود فروق دالة إحصـائيا بين متوسطات رتب درجات أفراد المجموعة التجريبية في الأداء البعدي والتتبعي على مقياس اللغـة التعبيرية، وكذلك عدم وجود فروق دالة إحصائيا بين متوسطات رتب درجات أفراد المجموعة التجريبية في الأداء البعدي والتتبعي على مقياس التواصل الاجتماعي. دراسة محمد (r ا ـ ب) بعنوان: أنماط التواصل الأسري وعلاقتها باللغة التعبيرية والتوافق النفسي لاى عينة من الأطفال ضعاف السمع. ولتحقيق أهداف الدراسة اعتمد الباحث على المنهج الوصفي من خلال استخدام استبانة التواصل الأسري الجزئي لضعاف السمح، واستبيان التواصل الأسري الكلي لضعاف السمع، ومقياس اللغة التعبيريـة، واستمارة بيانات أولية، والتي كانت من إعداد الباحث، ومقياس التوافق النفسي (إعداد محمد النوبي)، واختبار الذكاء غير اللفظي (إعداد فايزة المكرومي)، ومقياس المستوى الاقتصـادي والاجتماعي للأسرة (إعداد محمد فاروق فارهان). وتكونت عينة الدراسة من مئة طفل من ضعاف السمع في الصف الثالث، والرابع الابتدائي من مدينة القاهرة بنسبة فقد سمعي (0-0-70) ديسييل، وعمر زمني (9-r ( ) سنة. وتوصلت نتائج الدراسـة الى وجود فروق دالة إحصـائيًا بين متوسطات رتب الأطفال ضـعاف السمع ذوي نمط التواصل الكلي، ومتوسطات رتب الأطفال ضعاف السمع ذوي نمط التواصل الجزئي على مقياس التوافق النفسي لصالح ضعاف السمع المستخدمين لنمط التواصل الكلي من أفراد عينـة الدراسة، كمـا أكدت وجود فروق دالـة إحصـائيًا بين متوسطات رتب الأطفال ضـعاف السمع ذوي نمط التواصل الكلي ومتوسطات رتب الأطفال ضعاف السمع ذوي نمط التواصل الجزئي على مقياس اللغة التعبيريـة لصـالح ضعاف السمع المستخدمين لنمط التواصل الكلي من أفراد عينـة الدراسـة. وأكدت الدراسة على ضرورة دعم استخدام طريقة التواصل الكلي مع ضعاف السمع داخل محيط الأسرة لما لها من تأثير إيجابي على لغة ضعيف السمع التعبيرية، وتوافقه النفسي، ودعم برامج توعية وتعليم أولياء الأمور للجمع والتتويع بين أكثر من طريقة تواصل مع أطفالهم ضعاف السمع 


\section{المحور الثاني: الدراسات التي تناولت اللغة التعبيرية عند الأطفال ضعاف السمع.}

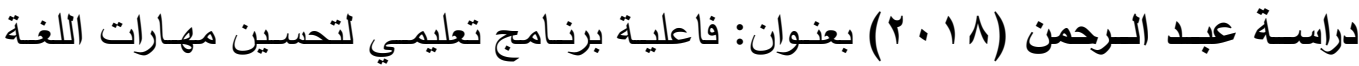

التعبيريـة للدى الأطفال ضـعاف السدع بالمركز السوداني للسمع. ولتحقيق أهداف الدراسـة اعتمد الباحث على المنهج شبه التجريبي مـن خـلال استخدام برنـامج تعليمي لتحسين مهارات اللغـة

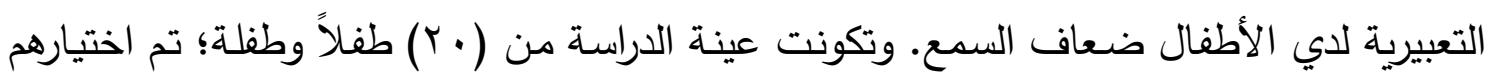
عن طريق الحصر الثامل. وتوصلت نتائج الدراسة الى وجود فروق ذات دلالة إحصائية بين نتائج

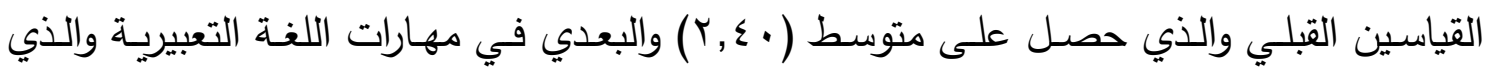

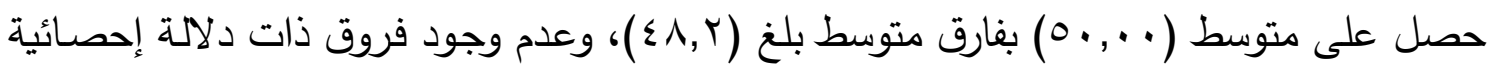
بين القياسين القبلي والبعدي في مهارات اللغة التعبيرية بين الذكور والإناث. دراسـة الحضري (Y (1 + ب) بعنوان: فاعلية برنامج تدريبي لتنمية مهارات اللغة الإستقبالية والتعبيرية وتحسين فاعلية الذات لاى عينة الأطفال ضعاف السمع. ولتحقيق أهداف الدراسة اعتمد الباحث على المنهج التجريبي من خـلال استخدام مقيـاس لمهـارات اللغــة الإستقبالية والتعبيريـة ومقياس فاعلية الذات بالإضـافة إلى البرنامج التدريبي من إعداد الباحثة. وتكونت عينة الدراسة من (• () أطفال تضمنت (0) ذكور ، و(0) إناث، تراوحت أعمارهم بين (· (1 I I ) سنوات. وتوصلت نتائج الدراسـة الى وجـود تأثير دال إحصـائيا للبرنـامج التـريبي لتتميـة مهارات اللغـة الإستقبالية والتعبيرية في تحسين فاعلية الذات، وأيضاً وجود فروق دالة إحصائياً في رتب درجات عينة الدارسة في القياسين القبلي والبعدي على مقياس مهارات اللغة الإستقبالية والتعبيريـة مما يشير إلى فاعلية البرنامج في تتمية اللغة الإستقبالية والتعبيرية.

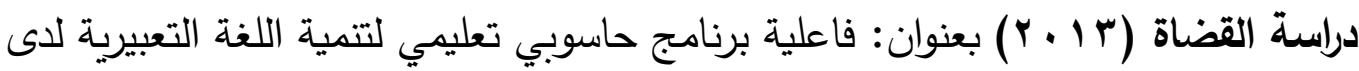
عينة من الطلبة ذوي الإعاقة السمعية البسيطة في الأردن. ولتحقيق أهداف الدراسة اعتمد الباحث على المنهج شبه التجريبي من خلال مقياس التعبير اللفظي الصوري للعمايرة، والبرنامج الحاسوبي

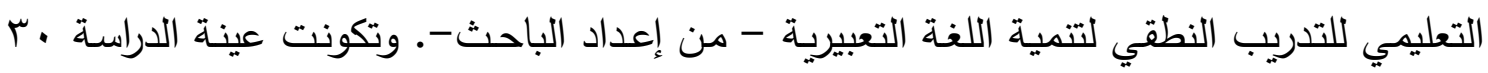

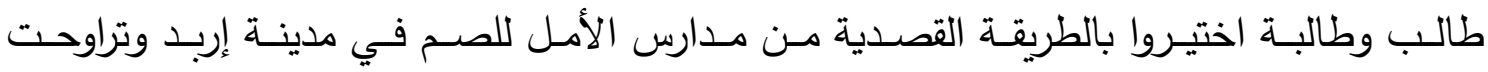

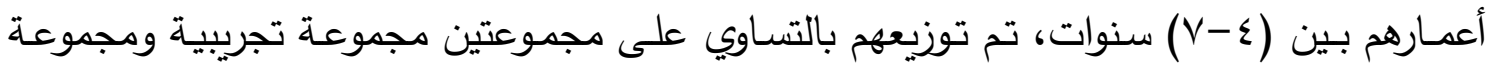


ضابطة. وتوصلت نتائج الدراسة الى هناك فروقاً ذات دلالة إحصائية في أداء الطلبة على الدرجة الكلية للقياس البعدي لمستوى اللغة التعبيرية لصـالح المجموعة التجريبية التي خضعت للبرنامج، مما يدل على فاعلية البرنامج لتنمية اللغة التعبيرية.

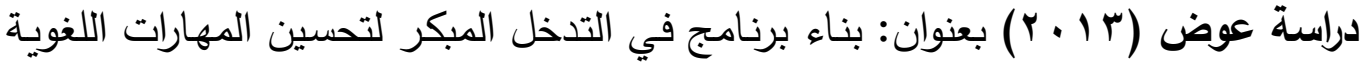
لاى الأطفال فاقدي السمع وقياس فاعليته. ولتحقيق أهداف الدراسة اعتمد الباحث على الدنهج شبه

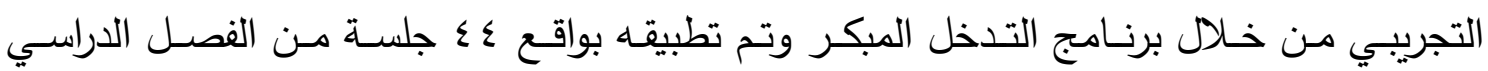
الثاني، ولقياس فاعليته تم بنـاء مقياسين مقياس مهارات اللغـة التعبيريـة ومقياس مهارات اللغــة الإستقبالية. وتكونت عينة الدراسة من · r طالباً اختيروا بطريقة قصدية ووزعوا على مجموعتين ضابطة وتجريبية. وتوصلت نتائج الدراسة الى وجود أثر فعال لبرنامج التدخل المبكر في تحسين مهارات اللغة الإستقبالية والتعبيرية.

\section{التعليــق علــى الــدراســات الســابقـــة}

بعد أن استعرض الباحث الدراسات السابقة التي أجريت في هذا الموضوع، وبعد تحليله

لها، يمكن تفصيل أوجه الثبه والاختلاف بين الدراسة الحالية والدراسات السابقة على النحو الاتي:

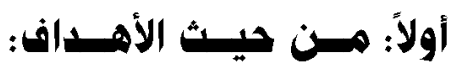
هدفت الدراسـة الحاليـة الى معرفـة دور الوالدين في تتميـة اللغـة التعبيريـة عند الاطففال ضـعاف السمح، واتفقت الدراسـة الحالية في هدفها مـع عدد من الدراسـات السـابقة مثل: دراسـة والتي هدفت الى معرفة دور التدخل المبكر في كفاءة الوالدين Davenport et al (Y.Y.) الذاتية لأولياء أمور الأطفال الصم وضعاف السمع، ودراسة سليمان (19 • ب) والتي هدفت الى معرفة فعالية برنامج إرشادي أسري لتمية الحصيلة اللغوية للأطفال ضعاف السمع المعاقين عقلياً،

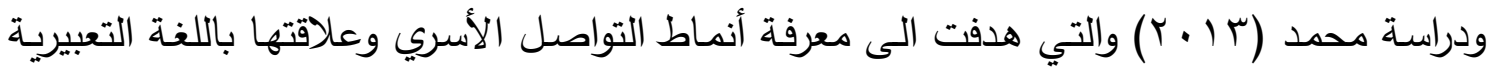

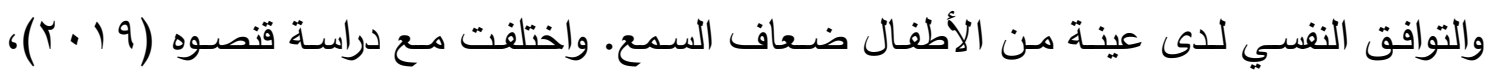

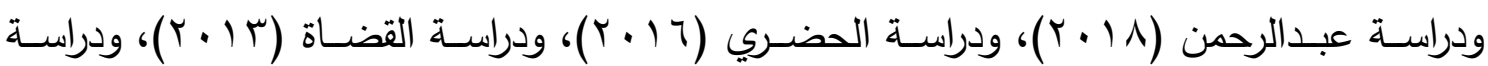

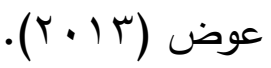




\section{ثانياً: مسـن حيــث المنهــهج:}

اعتمدت الدراسة الحالية على المنهج الوصفي التحليلي منهجاً للبحث، واتفق منهج الدراسة

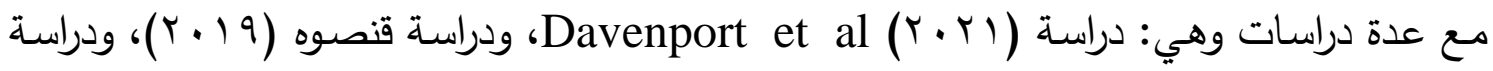

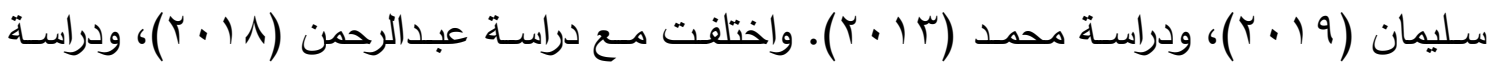

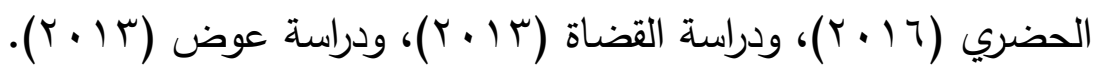

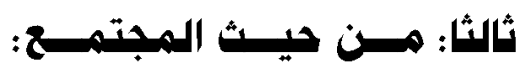

تكـون مجتمـع الدراسـة الحاليـة مـن والـدي الطفـل ضـعيف السـمع في المملكـة العربيـة

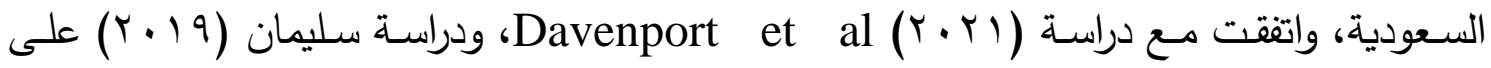
اختيارهم أسرة الطفل ضعيف السمع كمجتمع للدراسة. واختلفت مع دراسة قنصوه (9 ( ـ ب)، ودراسة

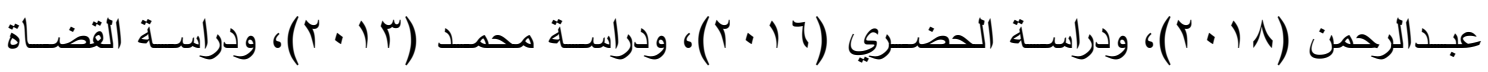



\section{رابعـاً: مسـن هـــــ الأداة:}

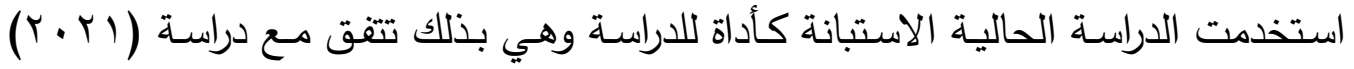
Davenport et al

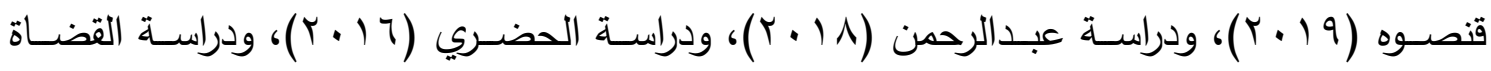

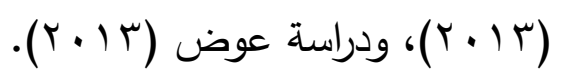

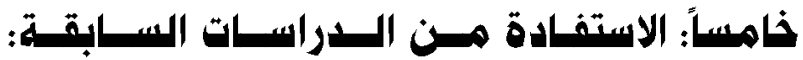

ا-تدعيم الاطار النظري بنتائج الدراسـات حول دور الوالدين في تتمية اللغـة التعبيريـة عند الأطفال ضعاف السمع. ץ- بناء مشكلة الدراسة من خلال إطلاع الباحثان على العديد من الدراسات السابقة. ب- اختيار منهج الدراسة الملائم والتعرف على نوع المعالجات الإحصائية المناسبة للدراسة. ع - سـاهمت الدراسـات السـابقة في التعـرف على أسـلوب استتتاج النتائج وذلك وفقـا لمـا تم الحصول عليه من معلومات من الدراسة الميدانية، ورصد مدى الاتفاق أو الاختلاف مع 


\section{منهـــة البـدراسـتة}

استخدم الباحثان المـنهج الوصـفي التحليلي، كونـهـ يسعى إلى معرفـة العوامـل والأحداث المعاصـرة والراهنـة في الواقع، ويـوفر بيانـات في غايـة الأهميـة خاصـة حينمـا يجري البحث في الميدان لأول مرة (المنصوري ، (Y · م).

\section{مجتمســـ البـدراسـة}

تكون مجتمـع الدراسـة مـن أسـر الطفل ضـعيف السـع، وتحديداً في المدارس الحكوميـة الملحقة بفصول ضعاف السمع، ومراكز ومعاهد التربية الخاصة التي تهتم بعلاج حالات اضطراب

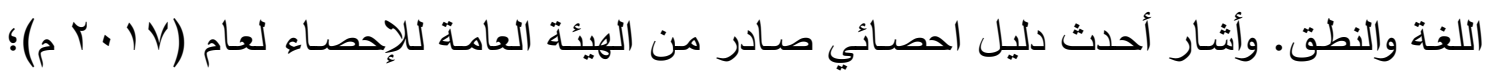
إلى أن نسبة الصسوبات السمعية (الخفيفة، والثديدة، والبالغـة) تمثل نسبة (ع, ( \%) من اجمالي

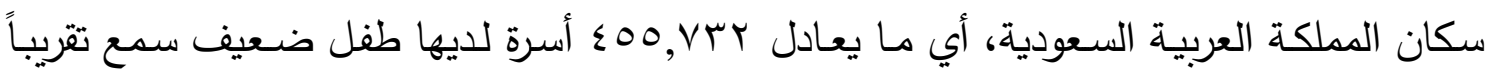

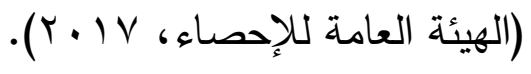

\section{عنئسة البسدراسبسة}

1- العينـة الاســطلاعية: بلــن حجم العينـة الاسـطلاعية (.ب) مـن أسـر الأطفـال ضـعاف السمع، تم اختيارهم بالطريقة القصدية من مجتمع الدراسـة، وذلك لتطبيق ادوات الدراسـة عليهح بهدف التحقق من معايير الصدق والثبات الخاصة بها. ץ- عينة الاراسة الرئيسية: اعتمد الباحثان على استخدام العينة العشوائية البسيطة؛ بحيث تم توزيـع الاستبانة على اسـر الطفل ضـعيف السـمع الكترونياً، ووصـلت عدد الاسـتجابات ( • ( ) استجابة من أسر الأطفال ضعاف السمع، وفيما يلي عرض تفصيلي لخصائص العينة ويوضحها الجدول رقم (1) كما يلي: 
جلول رقم (1) توزيع عينة الدراسة وفق المتفيرات الدراسة المختلفة

\begin{tabular}{|c|c|c|}
\hline النسبة المئوية & النسب التكرارات & متفــــيرات الــلـدراســـة \\
\hline & & 1- المستوى التعليمي لأحد الوالدين \\
\hline$\% 12,3$ & 48 & اقل من ثانوي \\
\hline$\% 21,5$ & 84 & ثانوية عامة \\
\hline$\% 20,8$ & 81 & 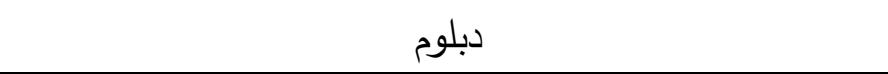 \\
\hline$\% 35,1$ & 137 & بكالوريوس \\
\hline \multirow[t]{2}{*}{$\% 10,3$} & 40 & دراسات عليا \\
\hline & & r - - جنس الطقل ضعيف السمع \\
\hline$\% 44,9$ & 175 & ذكر \\
\hline \multirow[t]{2}{*}{$\% 55,1$} & 215 & انثى \\
\hline & & r- - المرحلة الدراسية للطفل ضعيف السمع \\
\hline$\% 56,7$ & 221 & الصفوف الدنيا في المرحلة الابتدائية (اول - ثاني - ثالث) \\
\hline \multirow[t]{2}{*}{$\% 43,3$} & 169 & الصفوف العليا في المرحلة الابتدائية (رابع - خامس - سادس) \\
\hline & & ـ - درجة الفقدان السمعي للطفل \\
\hline$\% 29,7$ & 116 & 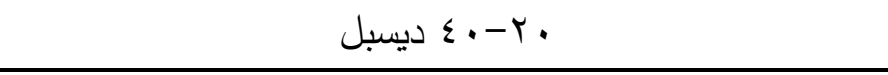 \\
\hline$\% 40,3$ & 157 & 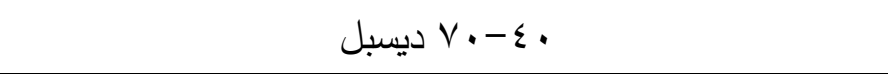 \\
\hline$\% 30$ & 117 & 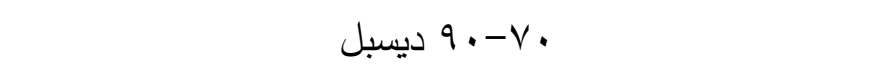 \\
\hline
\end{tabular}

ومن خلال استعراض النتائج في الجدول رقم ( ()، والذي يشمل توزيـع افراد عينة الدراسة وفقاً للمتغيرات المختلفة نستتتج الآتي:

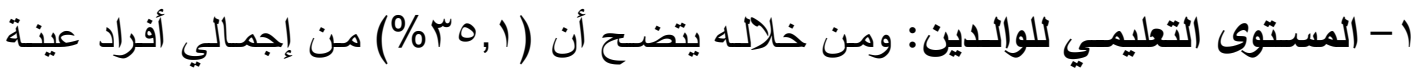
الدراسـة يمثلون (بكـالوريوس)، في حين أن (,0 1,0\%) مـن إجمـالي أفراد عينـة الدراسـة يمثلون (ثانويـة عامـة)، و (^, • r\%\%) من إجمـالي أفراد عينـة الدراسـة يمثلون (دبلوم)، و


إجمـالي أفراد عينـة الدراسـة يمثلون (دراسـات عليـا)، وهذه النتيجـة تدل على أن الغالبيـة العظمى من أفراد عينة الدراسة يمثلون الدرجة العلمية (بكالوريوس). 


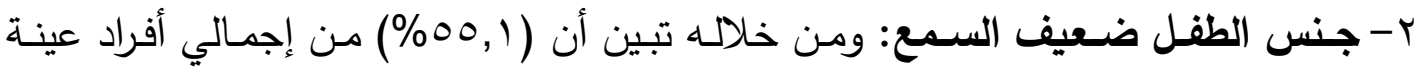
الدراسة يمثلون (انثى)، في حين أن (9, ؟ ؟ \%) من إجمالي أفراد عينة الدراسـة يمثلون (ذكر)، وهذه النتيجة تدل على التنوع في جنس أفراد عينة الدراسة.

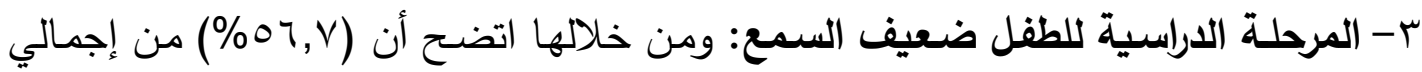

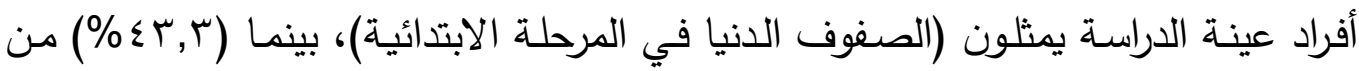

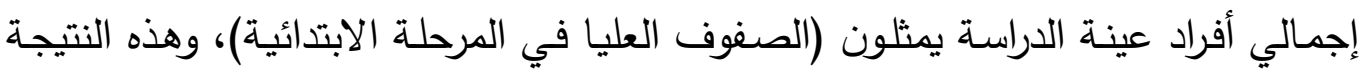
تلل على اهمية اختيار المراحل التعليمية الدختلفة لأفراد عينة الدراسة.

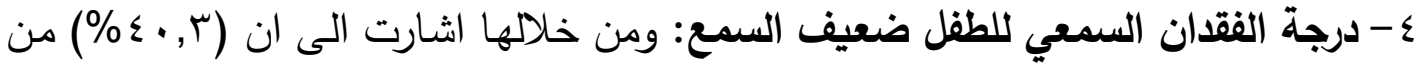

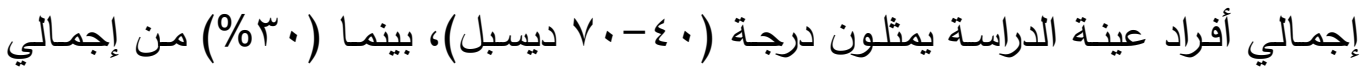

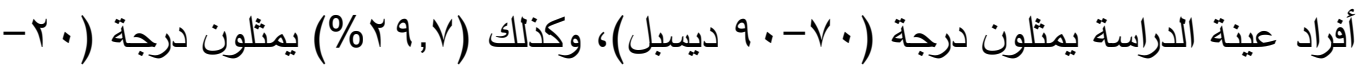
•ـ ديسبل)، وهذه النتيجة تدل على اهميـة مراعـاة الفروق المختلفة في درجـة الفقدان

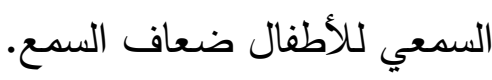

\section{صــلـ أداة الـــدراســة}

تحقق الباحثان من صدق الأداة وذلك باتباع الإجراءات التالية:

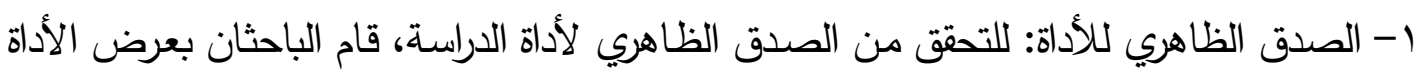
بصورتها الاولية على ؛ محكمين من ذوي الاختصاص في مجال التربية الخاصة لتحكيمها،

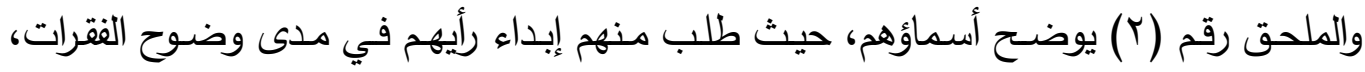
ومدى انتماء العبارة للبعد، وبنائها اللغوي، ومدى مناسبة فقرات فرات الاستبانة للأبعاد التي تقيسها، وعلى ضوء توجيهاتهم ومقترحاتهم أجرى الباحثان بعض التعديلات على الاستبانة.

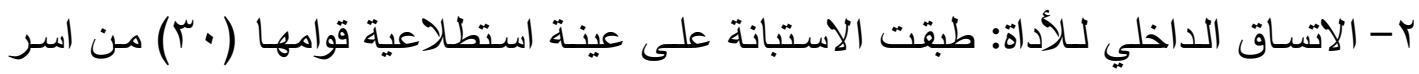

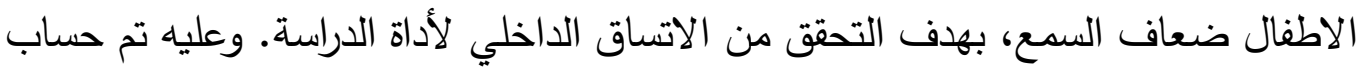
التجانس الداخلي للاستبانة r- عن طريق حساب معامل الارتباط بيرسون ويبن درجات الأفراد على كل عبارة من عبارات الاستبانة والدرجة الكلية للاستبانة. وفيما يلي الجدول رقم (؟) يوضح قيم معامل ارتباط بيرسون بين الدرجة الكلية للاستبانة ومحاورها: 
جلدول رقم (r) قيم معامل ارتباط بيرسون بين الدرجة الكلية للاستبانة ومحاورها

\begin{tabular}{|c|c|c|c|}
\hline 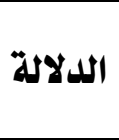 & $\begin{array}{l}\text { معامل الارتباط } \\
\text { معباط }\end{array}$ & 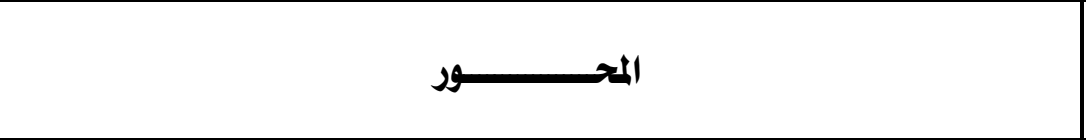 & رقمر \\
\hline عالي & $0.864 * *$ & العوامل البيئية المرتبطة بوالدي ضعيف السمع والتي تؤثر على لغته التعبيرية & 1 \\
\hline 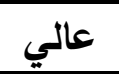 & $0.847 * *$ & العوامل الاجتماعية المرتبطة بوالدي ضعيف السمع والتي تؤثر على لغته التعبيرية & $\begin{array}{r} \\
\end{array}$ \\
\hline 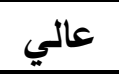 & $0.861 * *$ & |العوامل النفسية المرتبطة بوالدي ضعيف السمع والتي تؤثر على لغته التعبيرية & $r$ \\
\hline عالي & $0.910 * *$ & |العوامل البيئية المرتبطة بوالدي ضعيف السمع والتي تؤثر على لغته التعبيرية & $\varepsilon$ \\
\hline
\end{tabular}

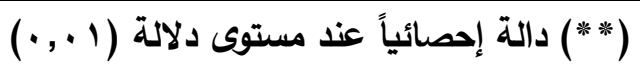

يتبين من الجدول رقم (r)؛ ان جميع معاملات الارتباط دالة إحصائياً عند مستوى دلالة ( ( •. •)، مما يشير إلى وجود علاقة ارتباط قويـة بين كل محور من محاور الاستبانة بالدرجة الكلية للاستبانة، وهذا يعطي دلالة على ارتفاع الاتساق الداخلي لمحاور الاستبانة، مما يدل على أن الاستبانة تعد صادقة فيما وضعت لقياسه، وتحقق الهدف من الدراسة، وهذا يشير إلى إمكانية الوثوق بنتائج الدراسة.

\section{ثبـــــات أداة الـــلــراســــة}

استخدم الباحثان لحساب ثبات المقياس طريقة ألفا كرو نباخ، وطريقة التجزئة النصفية، وبلغخ معامل الثبات للمقياس ككل لمعامل ألفا كرو نباخ (Y7 9 , •)، اما بالنسبة للتجزئة النصفية فبينت النتيجة (ع (ج, •))، كما هو موضتح في الجدول رقم (ب) وهو كما يلي:

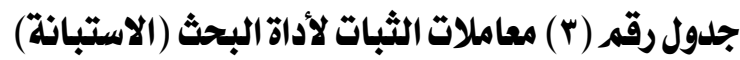

\begin{tabular}{|c|c|c|c|c|}
\hline التجزئة النصفية & ألفا كرونباخ & علد الفقرات & 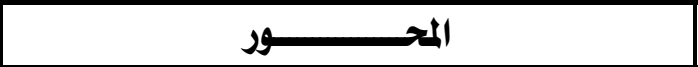 & رقم المحور \\
\hline 0.874 & 0.912 & 7 & 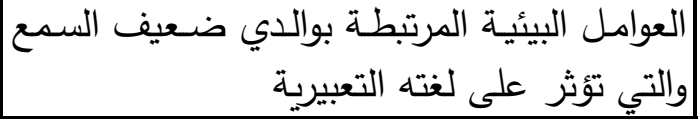 & 1 \\
\hline 0.847 & 0.873 & 4 & 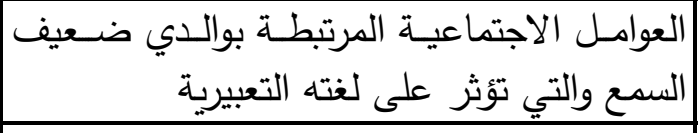 & $r$ \\
\hline 0.854 & 0.911 & 6 & 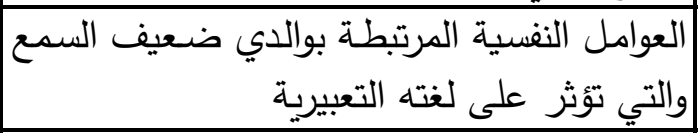 & $r$ \\
\hline 0.906 & 0.932 & 8 & 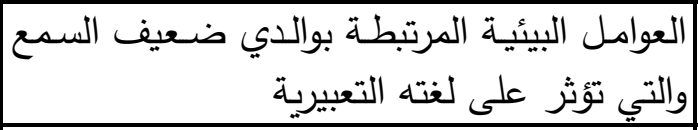 & $\varepsilon$ \\
\hline 0.914 & 0.962 & 25 & الثبات العام للاستبانة & \\
\hline
\end{tabular}




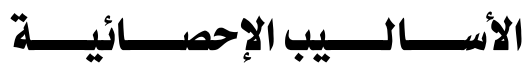

استخدم الباحثان عدداً من الأسـاليب الإحصائية؛ لمعرفة دور أفراد عينة الدراسـة حول التساؤلات المطروحة، وذلك باستخدام برنامج التحليل الإحصائي للعلوم الاجتماعية (SPSS)، وسنذكر الأساليب كما يلي: 1- التكرارات والنسب المئوية؛ للتعرف على الخصائص الشخصية والوظيفية لعينـة الدراسة، وتحديد استجاباتهم تجاه عبارات المحاور الرئيسة التي تضمنتها الدراسة. r- المتوسط الحسابي (Mean)؛؛ لمعرفة مدى ارتفاع استجابات أفراد العينة أو انخفاضها على كل عبارة من عبارات متغيرات الدراسة الرئيسة بحسب محاور الاستبانة، مع العلم بأنه يفيد في ترتيب العبارات حسب أعلى متوسط حسابي موزون. r- الانحراف المعياري (Standard Deviation)؛ للتعرف على مدى انحراف استجابات أفراد العينة لكل عبارة من عبارات محاور الدراسة، ولكل محور رئيس عن متوسطه الحسابي، فكلما اقتربت قيمته من الصفر ؛ تركزت الاستجابات وانخفض تشتتها بين المقياس. ع- معامل الارتباط بيرسون (Person Correlation)؛ لمعرفة درجة الارتباط بين كل عبارة من عبارات الاستبانة، والدرجة الكلية للدحور الذي تتتمي إليه العبارة . ه- معادلة ألفا كرونباخ (Cronbach'a Alpha) والتجزئة النصفية؛ للتحقق من ثبات أداة الدراسة وصلاحيتها للتطبيق. צ- اختبار (ت) لعينتين مستقلتين (Independent Sample t-test)؛ للتعرف على دور الوالدين في تتمية اللغة التعبيرية عند الأطفال ضعاف السمع، تبعاً لمتغير جنس الطفل ضعيف السمع (ذكر ، انثى)، ومتغير المرحلة الدراسية للطفل (الصفوف الدنيا في المرحلة الابتدائية، الصفوف العليا في المرحلة الابتدائية). V- اختبار تحليل التباين الأحادي (One-Way ANOVA)؛ للتعرف على مدى اختلاف استجابات عينة استبانة دور الوالدين في تنمية اللغة التعبيرية عند الأطفال ضعاف السمع، تبعاً لمتغير المستوى التعليمي لأحد الوالدين ودرجة الفقدان السمعي للطفل ضعيف السمع. 
واستخدم الباحثان (مقياس ليكرت الخماسي)؛ كونه سهل الإعداد والتطبيق، ويعطي درجة ايجابية او سلبية تجاه كل عبارة من عبارة، كما يوضحه الجدول رقم (ع) كما يلي: جلدول رقم (§) توزيع ليكرت الخماسي لمستوى الأوزان

\begin{tabular}{|c|c|c|c|c|c|c|}
\hline \multirow{2}{*}{ القيمة } & \multirow{2}{*}{ الترميز } & \multirow{2}{*}{ مستوى الاستجابة } & \multicolumn{2}{|c|}{ الوزن النسبي } & \multicolumn{2}{|c|}{ المتوسط الحسابي } \\
\hline & & & إلى إلى & من & إلى & من من \\
\hline ضعيف جداً & 1 & غير موافق بشدة & 36.00 & 20.00 & 1.80 & 1 \\
\hline ضعيف & 2 & غير موافق & 52.00 & 36.20 & 2.60 & 1.81 \\
\hline متوسط & 3 & محايد & 68.00 & 52.20 & 3.40 & 2.61 \\
\hline كبيرة & 4 & موافق & 84.00 & 68.20 & 4.20 & 3.41 \\
\hline كبيرة جدا & 5 & موافق بشدة & 100.00 & 84.20 & 5 & 4.21 \\
\hline
\end{tabular}

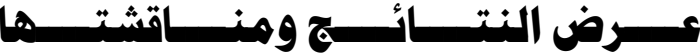

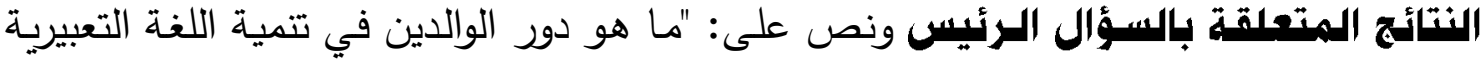

$$
\text { عند الاطفال ضعاف السمح؟" }
$$

للتعرف على دور الوالدين في تتمية اللغة التعبيريـة عند الأطفال ضـعاف السمع، تم حساب المتوسطات الحسـابية والانحرافات المعياريـة والوزن النسبي والرتب لاستجابات المعلمين على محاور استبانة دور الوالدين في تتمية اللغـة التعبيريـة عند الأطفال ضـعاف السمع، وسوف يتم الاعتمـاد في تقسير النتائج بناء على مقياس ليكرت الخماسي، وجاءت النتائج كما هو موضتح في الجدول رقم (0):

جلول رقم (0) المتوسطات الحسابية والانحرافات المعيارية والأوزان النسبية والرتب

\begin{tabular}{|c|c|c|c|c|c|c|}
\hline المواققة & الرتب & النسبي & الإنحراف & الحسابي & المحــــــــور & رقمى \\
\hline كبيرة & 4 & 76.2 & 0.909 & 3.81 & ضعيف السمع والتي تؤثر على لغتئية المرتبط التعبيرية & 1 \\
\hline كبيرة & 3 & 76.8 & 0.909 & 3.84 &  & r \\
\hline كبيرة & 1 & 79.4 & 0.884 & 3.97 & 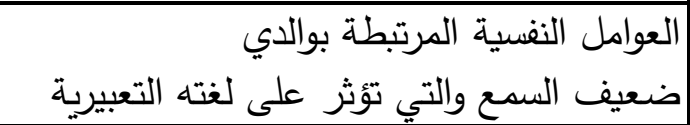 & r \\
\hline كبيرة & 2 & 77.8 & 0.920 & 3.89 & ضعيف السمع الثقافية المرتبطة بوالدي تلتئي لغته التعبيرية & $\varepsilon$ \\
\hline كبيرة & & 77.6 & 0.794 & 3.88 & 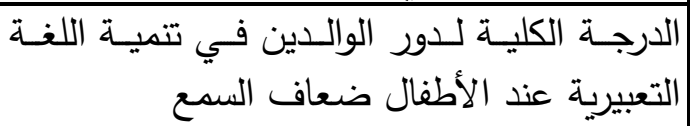 & \\
\hline
\end{tabular}


يتضح من خلال النتائج الموضحة في الجدول رقم (0)؛ أن درجة استبانة دور الوالدين في

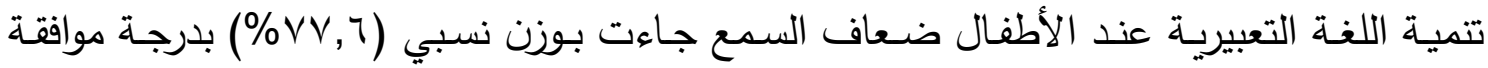
كبيرة. كما يتضح أن محور العوامل النفسية المرتبطة بوالدي ضعيف السمع والتي تتؤثر على لغته التعبيرية جاء في مقدمة المحاور وذلك بوزن نسبي (؟ \&9\%) وبدرجة موافقة كبيرة، يليه محور العوامل الثقافية المرتبطة بوالدي ضعيف السمع والتي تؤثر على لغته التعبيرية جاء بوزن نسبي

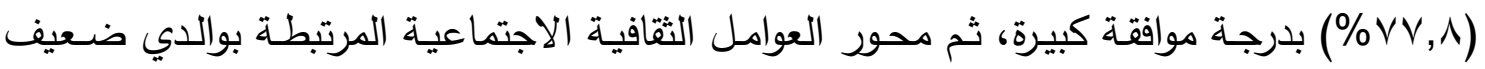

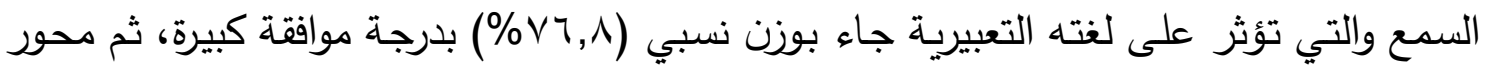
العوامل البيئية المرتبطة بوالدي ضعيف السمع والتي تؤثر على لغته التعبيرية جاء بوزن نسبي

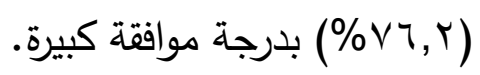

تتفق هذه النتيجة مع دراسة ( Davenport et al (r ( ) والذين توصلوا الى اهمية مستوى مشاركة الوالدين، واهمية التدخل المبكر لأولياء امور الاطفال الصم وضعاف السمع، في اتخاذ القرار بشأن أهداف الخطة الفردية لخدمة الأسرة، وأنواع الخدمات، ومقدار الخدمات. واتفقت الته ايضاً مع دراسة (سليمان، 9 (ب) والتي توصلت الى فاعلية برنامج الإرشاد الأسري في تتمية الحصيلة اللغوية للأطفال ضعاف السمع المعاقين عقلياً.

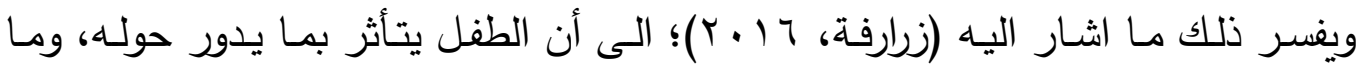
يعيثه من حياة أسرية، وعلاقات اجتماعية، أههها العلاقة بين الأب والأم، والتي تعد من أكبر المؤثرات على تتمية اللغة التعبيريـة لديه منذ صغره العلاقات الأسرية بين الوالدين داخل الأسرة، حيث يتأثر الطفل بوجود السعادة الأسرية، ويتأثر أيضا بوجود المشكلات الأسرية والتفكك الأسري. ويمكن للباحث بناء على النتائج السابقة الإثارة الى ان العوامل النفسية شكلت اهم محاور الدراسة؛ لما لها من اهمية كبرى في تتمية اللغة التعبيرية عند الطفل ضعيف السمع، واهمية دور الوالدين في مراعاة الجانب النفسي، والضغوطات النفسية لطفلهم ضعيف السمع، وسعي الوالدين الى تطوير العلاقة بشكل ايجابي مع طفلهم، وتجنب الخلافات ما بين الوالدين، كل ذلك يساهم بثكل كبير على تحسن الجانب النفسي للطفل ضعيف السمع. 
النتائج المتعاقة بالسؤال الفرعي الأول ونص على: "ما مدى الاختلاف في استجابات الوالدين حول دورهم في تتمية اللغة التعبيرية عند الطفل ضعيف السمع تبعاً إلى المستوى التعليمي

لأحد الوالدين (أقل من ثانوي، ثانوية العامة، دبلوم، بكالوريوس، دراسات عليا)؟" استخدم الباحثان الاختبارات المعملية؛ للتعرف على مدى الاختلاف حول دور الوالدين في تتمية اللغة التعبيرية عند الاطفال ضعاف السمع لمتغير المستوى التعليمي لأحد الوالدين، والاختبار المناسب هنا هو اختبار تحليل التباين الأحادي (One- Way ANOVA)، وجاءت النتائج كما

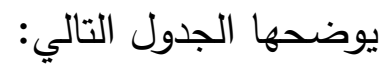
جلدول رقم (1) نتائج اختبار تحليل التباين الاحادي (ف) للتعرف على مدى الاختلاف حول دور الوالدين في تنمية اللفة التعبيرية عند الاطفال ضعاف السمع التي تعزى لتتفير المستوى التعليمي لأحد الواللدين

\begin{tabular}{|c|c|c|c|c|c|c|c|}
\hline \multicolumn{2}{|c|}{ الإحصائية اللالة } & قيمة ف & متوسط المربعات & |الحرية & مجموع المربعات & المجموعات & الماحـــــــــور \\
\hline \multirow{3}{*}{ | دالة } & \multirow{3}{*}{0.000} & \multirow{3}{*}{5.440} & 4.308 & 4 & 17.232 & بين المجموعات & \multirow{3}{*}{ بوالدي ضعوامل البيئية المرتبطة الدية لعدع والتي } \\
\hline & & & 0.792 & 385 & 304.878 & داخل المجموعات & \\
\hline & & & & 389 & 322.110 & المجموع & \\
\hline \multirow{3}{*}{ | دالة } & \multirow{3}{*}{0.004} & \multirow{3}{*}{3.914} & 3.139 & 4 & 12.554 & بين المجموعات & \multirow{3}{*}{ توألثوامل الاجتماعية المرتبطة ضعلى لغتيف السمع والتي } \\
\hline & & & 0.802 & 385 & 308.743 & داخل المجموعات & \\
\hline & & & & 389 & 321.297 & المجموع & \\
\hline \multirow{3}{*}{ | دالة } & \multirow{3}{*}{0.000} & \multirow{3}{*}{6.802} & 5.026 & 4 & 20.103 & بين المجموعات & \multirow{3}{*}{ بوالدي العوامل النفسية المرتبطة على السية لغته التعبية } \\
\hline & & & 0.739 & 385 & 284.476 & داخل المجموعات & \\
\hline & & & & 389 & 304.578 & المجموع & \\
\hline \multirow{3}{*}{ | دالة } & \multirow{3}{*}{0.002} & \multirow{3}{*}{4.414} & 3.611 & 4 & 14.444 & بين المجموعات & \multirow{3}{*}{ بوالدي ضعوامل الثقافية المرتبطة } \\
\hline & & & 0.818 & 385 & 314.940 & داخل المجموعات & \\
\hline & & & & 389 & 329.384 & المجموع & \\
\hline \multirow{3}{*}{ | دالة } & \multirow{3}{*}{0.000} & \multirow{3}{*}{6.416} & 3.833 & 4 & 15.331 & بين المجموعات & \multirow{3}{*}{ الدرجة الكلية } \\
\hline & & & 0.597 & 385 & 229.980 & داخل المجموعات & \\
\hline & & & & 389 & 245.312 & المجموع & \\
\hline
\end{tabular}

دالة عند مستوى دلالة 0.05 فأقل. 
يتضح من خلال النتائج في الجدول رقم (ך)؛ وجود فروق ذات دلالة إحصائية عند مستوى دلالة (0., •) في دور الوالدين في تتمية اللغة التعبيرية عند الاطفال ضعاف السمع حول (العوامل البيئية، العوامل الاجتماعية، العوامل النفسية، العوامل الثقافية) المرتبطة بوالدي ضعيف السمع والتي تؤثر على لغته التعبيرية تعزى لمتغير المستوى التعليمي لأحد الوالدين لصالح الذين مستواهم التعليمي بكالوريوس.


وعلاقتها باللغة التعبيرية والتوافق النفسي لدى عينة من الأطفال ضعاف السمع، وطبق الباحث

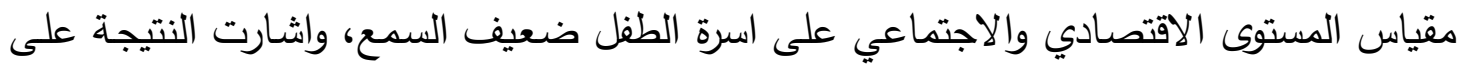
وجود فروق ذات دلالمة احصـائية، واكدت ايضـاً على دعم برامج توعية وتعليم أولياء الأمور

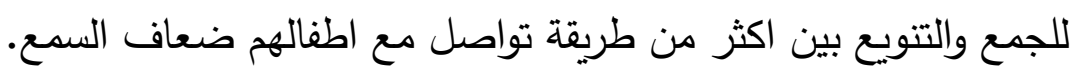

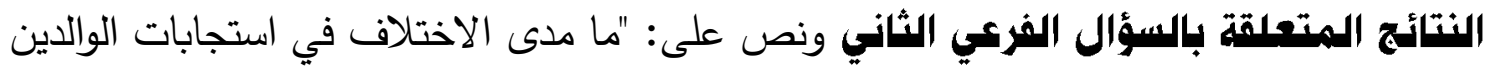

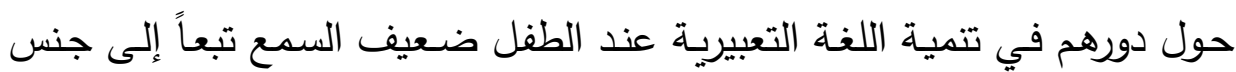

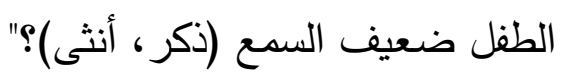

للإجابة عن هذا السؤال استخدم الباحثان اختبار (ت) لعينتين مستقلتين ( independent (sample t-test

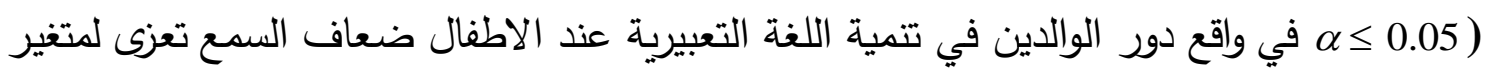

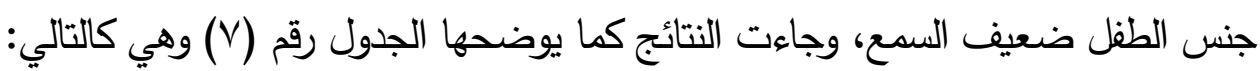

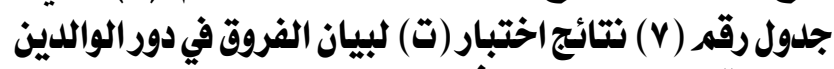

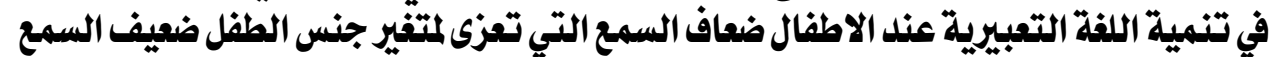

\begin{tabular}{|c|c|c|c|c|c|c|c|c|}
\hline \multicolumn{2}{|c|}{ الإحصائية } & الحربة & قيمة ت & الانمراف & الحسابي & العدد & i & - سور \\
\hline \multirow{2}{*}{ دا } & \multirow{2}{*}{0.007} & \multirow{2}{*}{388} & \multirow{2}{*}{2.727} & 0.953 & 3.67 & 175 & ذكر & \multirow{2}{*}{ 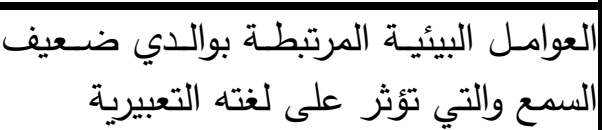 } \\
\hline & & & & 0.859 & 3.92 & 215 & أنثى & \\
\hline \multirow{2}{*}{ دالة } & \multirow{2}{*}{0.077} & \multirow{2}{*}{388} & \multirow{2}{*}{1.775} & 0.941 & 3.75 & 175 & ذكر & \multirow{2}{*}{ 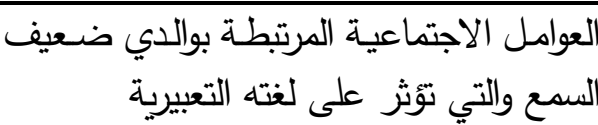 } \\
\hline & & & & 0.876 & 3.92 & 215 & أنثى & \\
\hline \multirow{2}{*}{ |دا } & \multirow{2}{*}{0.035} & \multirow{2}{*}{388} & \multirow{2}{*}{2.114} & 0.918 & 3.86 & 175 & ذكر & \multirow{2}{*}{ 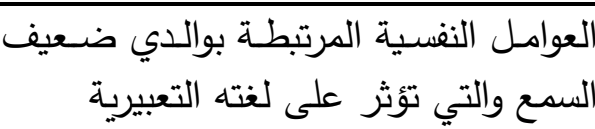 } \\
\hline & & & & 0.848 & 4.05 & 215 & أنثى & \\
\hline \multirow{2}{*}{ |دالة } & \multirow{2}{*}{0.000} & \multirow{2}{*}{388} & \multirow{2}{*}{4.115} & 0.973 & 3.69 & 175 & ذكر & \multirow{2}{*}{ 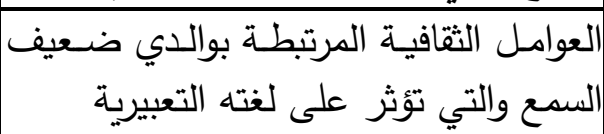 } \\
\hline & & & & 0.838 & 4.06 & 215 & أنثى & \\
\hline \multirow{2}{*}{ |دالة } & \multirow{2}{*}{0.001} & \multirow{2}{*}{388} & \multirow{2}{*}{3.291} & 0.821 & 3.74 & 175 & ذكر & \multirow{2}{*}{ الدرجة الكلية } \\
\hline & & & & 0.752 & 4.00 & 215 & أنثى & \\
\hline
\end{tabular}

دالة عند مستوى دلالة 0.05 فأقلى. 
يتضـح من خـلال النتائج الموضـحة في جدول رقم (V)؛ يتضـح عدم وجود فروق ذات دلالـة

إحصائية عند مستوى دلالة (0. . •) في دور الوالدين في تتمية اللغة التعبيرية عند الاطفال ضعاف السمع حول العوامل الاجتماعية المرتبطة بوالدي ضعيف السمع والتي تؤثر على لغته التعبيريـة تعزى لمتغير جنس الطفل ضعيف السمع. كما اتضح من خلال النتائج ايضاً وجود فروق ذات دلالة إحصائية عند مستوى دلالة (0. . •) في دور الوالدين في تتمية اللغة التعبيرية عند الاطفال ضعاف السمع حول (العوامل البيئية والعوامل النفسية والعوامل الثقافية) المرتبطـة بوالدي ضـعيف السـع والتي تؤثر على لغته التعبيرية تعزى لمتغير جنس الطفل ضعيف السمع لصالح الأطفال الذكور . تتفق هذه النتيجة مع دراسة (عبد الرحمن، 11 ـ ب) والتي كان هدفها: فاعلية برنامج تعليمي لتحسين مهارات اللغة التعبيريـة لدى الأطفال ضـعاف السمع، واستخدم الباحث فيها برنـامج تعليمي لتحسين مهارات اللغـة التعبيريـة عند الاطفال ضـعاف السمع، والتي توصلت الى عدم وجود فروق ذات دلالة احصائية بين القياسين القبلي والبعدي في مهارات اللغة التعبيرية بين الذكور والإناث. النتائج المتعالقة بالسؤال الفروي الثالث ونص على: "ما مدى الاختلاف في استجابات الوالدين حول دورهم في تنمية اللغة التعبيريـة عند الطفل ضعيف السمع تبعاً إلى المرحلة الدراسية للطفل ضعيف السمع (الصفوف الدنيا في المرحلة الابتدائية، الصفوف

$$
\text { العليا في المرحلة الابتدائية)؟" }
$$

استخدم الباحثان للإجابة عن هذا السؤال اختبار (ت) لعينتين مستقلتين ( independent (sample t-test)؛ للتعرف على ما إذا كانت هناك فروق ذات دلالة إحصائية عند مستوى دلالة ( os 0.05 في واقع دور الوالدين في تنمية اللغة التعبيرية عند الاطفال ضعاف السمع تعزى لمتغير المرحلة الدراسية للطفل ضعيف السمع، وجاءت النتائج كما يوضحها الجدول رقم (^) وهي كالتالي: 
جدول رقير (^) نتائج اختبار (ت) لبيان الفروق في دور الوالدين

\begin{tabular}{|c|c|c|c|c|c|c|c|c|}
\hline \multicolumn{2}{|c|}{ الإحصائية اللالة } & |درجة |الحرية & قيمة ت & الالمزياري & |المتوبط الحسابي & العلد & |المرحلة الدراسيةة & الملحـــــــــــور \\
\hline \multirow{2}{*}{ 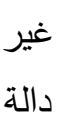 } & \multirow{2}{*}{0.086} & \multirow{2}{*}{388} & \multirow{2}{*}{1.722} & 0.944 & 3.74 & 221 & ال الدنيا & \multirow{2}{*}{ 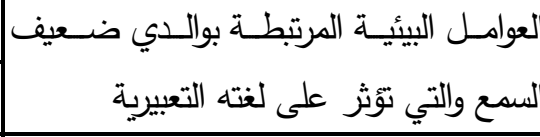 } \\
\hline & & & & 0.857 & 3.90 & 169 & العليا & \\
\hline \multirow{2}{*}{ 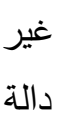 } & \multirow{2}{*}{0.260} & \multirow{2}{*}{388} & \multirow{2}{*}{1.129} & 0.913 & 3.80 & 221 & ال الدنيا & \multirow{2}{*}{ العوامل الاجتماعية المرتبطة بوالدي ضعيف } \\
\hline & & & & 0.901 & 3.90 & 169 & العليا & \\
\hline \multirow{2}{*}{ 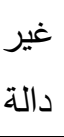 } & \multirow{2}{*}{0.306} & \multirow{2}{*}{388} & \multirow{2}{*}{1.026} & 0.941 & 3.93 & 221 & الدنيا & \multirow{2}{*}{ 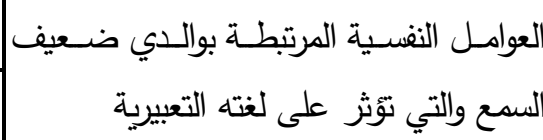 } \\
\hline & & & & 0.804 & 4.02 & 169 & العليا & \\
\hline \multirow{2}{*}{ دالة } & \multirow{2}{*}{0.040} & \multirow{2}{*}{388} & \multirow{2}{*}{2.056} & 0.931 & 3.81 & 221 & الدنيا & \multirow{2}{*}{  } \\
\hline & & & & 0.896 & 4.00 & 169 & العليا & \\
\hline \multirow{2}{*}{ غير } & \multirow{2}{*}{0.073} & \multirow{2}{*}{388} & \multirow{2}{*}{1.797} & 0.819 & 3.82 & 221 & الدنيا & \multirow{2}{*}{ الدرجة الكلية } \\
\hline & & & & 0.754 & 3.96 & 169 & العليا & \\
\hline
\end{tabular}

دالة عند مستوى دلالة 0.05 فأقل.

يتضح من خلال النتائج في الجدول رقم (^)؛ عدم وجود فروق ذات دلالة إحصائية عند مستوى

دلالة (0. . •) في دور الوالدين في تنمية اللغة التعبيريـة عند الاطفال ضـعاف السمع حول (العوامل البيئية والعوامل الاجتماعية والعوامل النفسية) المرتبطة بوالدي ضعيف السمع والتي تؤثر على لغته التعبيرية تعزى لمتغير المرحلة الدراسية للطفل ضعيف السمع. كما يتضـح من خلال النتائج وجود فروق ذات دلالة إحصائية عند مستوى دلالة (0. . •) في دور الوالدين في تتمية اللغـة التعبيريـة عند الاطفال ضعاف السمع حول العوامل الثقافية المرتبطة بوالدي ضعيف السمع والتي تؤثر على لغته التعبيرية تعزى لمتغير المرحلة الدراسية للطفل ضعيف السمع، وذلك لصالح الأطفال الذين يمثلون الصفوف الدنيا في المرحلة الابتدائية. تتقق هذه النتيجة مع دراسة (محمد، ب ( ب ) والتي كان هدفها: أنماط التواصل الأسري وعلاقتها باللغة التعبيرية والتوافق النفسي لدى عينة من الأطفال ضعاف السمع، وتكونت عينة الدراسة من الصف الثالث الذي ينتمي للحدود الدنيا، والصف الرابع للحدود العليا، واشارت النتائج في هذه الدراسة على وجود فروق ذات دلالة احصائية بين العمر الزمني (و-r ( ) سنة، واكدت ايضـاً على دعم برامج توعية وتعليم أولياء الأمور للجمع والتتويع بين اكثر من طريقة تواصل مع اطفالهم ضعاف السمع. 
النتائج المتعلقة بالسؤال الفرعي الرابع ونص على: "ما مدى الاختلاف في استجابات الوالدين

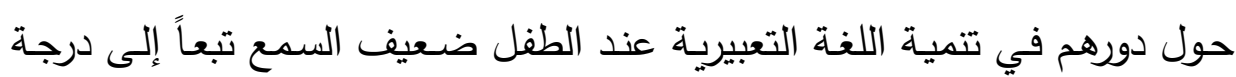

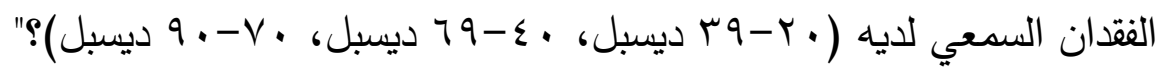

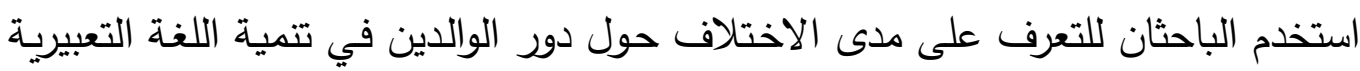

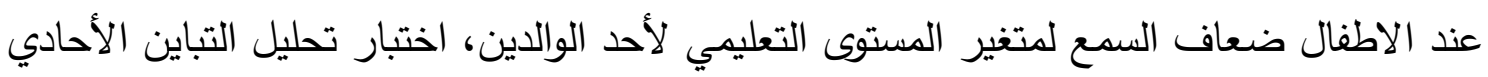

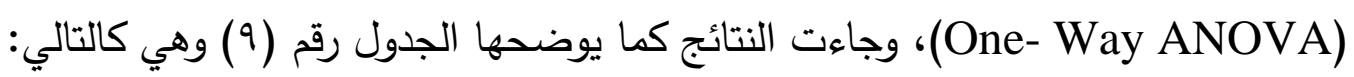

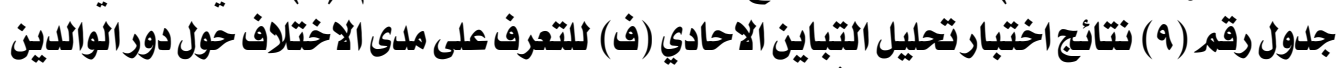

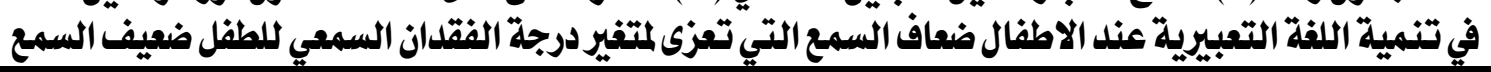

\begin{tabular}{|c|c|c|c|c|c|c|c|}
\hline \multicolumn{2}{|c|}{ الإحصائية } & قيمة ف & متوسط & الحرجية & مجمبوع & المجموعات & المحور \\
\hline \multirow{3}{*}{ دالة } & \multirow{3}{*}{0.031} & \multirow{3}{*}{3.508} & 2.868 & 2 & 5.736 & بين المجموعات & \multirow{3}{*}{ 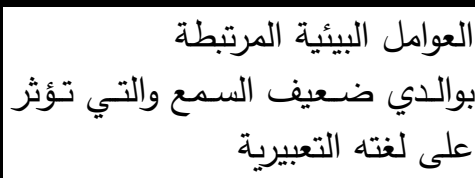 } \\
\hline & & & 0.818 & 387 & 316.374 & داخل المجموعات & \\
\hline & & & & 389 & 322.110 & المجموع & \\
\hline \multirow{3}{*}{ | دالة } & \multirow{3}{*}{0.049} & \multirow{3}{*}{3.032} & 2.479 & 2 & 4.957 & بين المجموعات & \multirow{3}{*}{ 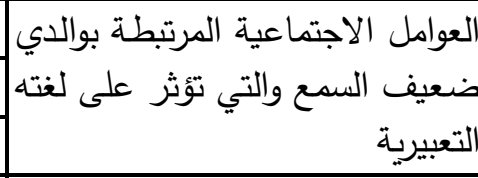 } \\
\hline & & & 0.817 & 387 & 316.340 & داخل المجموعات & \\
\hline & & & & 389 & 321.297 & المجموع & \\
\hline \multirow{3}{*}{ | ب دالة } & \multirow{3}{*}{0.019} & \multirow{3}{*}{4.028} & 3.106 & 2 & 6.212 & بين المجموعات & \multirow{3}{*}{ 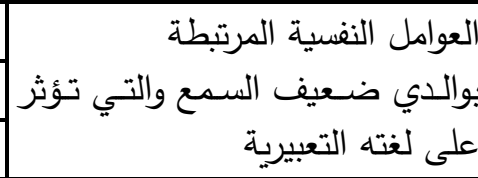 } \\
\hline & & & 0.771 & 387 & 298.367 & داخل المجموعات & \\
\hline & & & & 389 & 304.578 & المجموع & \\
\hline \multirow{3}{*}{ | دالة } & \multirow{3}{*}{0.035} & \multirow{3}{*}{3.367} & 2.817 & 2 & 5.634 & بين المجموعات & \multirow{3}{*}{ 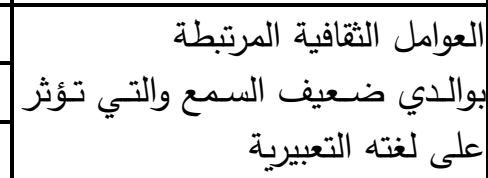 } \\
\hline & & & 0.837 & 387 & 323.750 & داخل المجموعات & \\
\hline & & & & 389 & 329.384 & المجموع & \\
\hline \multirow{3}{*}{ | دالة } & \multirow{3}{*}{0.013} & \multirow{3}{*}{4.382} & 2.716 & 2 & 5.432 & بين المجموعات & \multirow{3}{*}{ الدرجة الكلية } \\
\hline & & & 0.620 & 387 & 239.880 & داخل المجموعات & \\
\hline & & & & 389 & 245.312 & الدجموع & \\
\hline
\end{tabular}

دالة عند مستوى دلالة 0.05 فأقل.

يتضح من خلال النتائج في الجدول رقم (9)؛ انه يوجد فروق ذات دلالة إحصائية عند مستوى دلالة (0., •) في دور الوالدين في تتمية اللغة التعبيرية عند الاطفال ضعاف السمع حول (العوامل

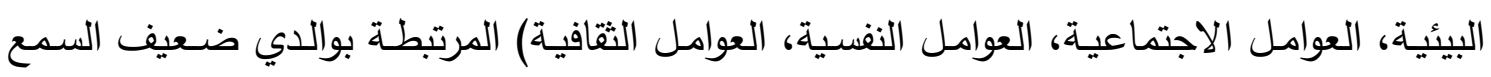
والتي تؤثر على لغته التعبيرية تعزى لمتغير درجة الفقدان السمعي للطفل ضعيف السمع، وذلك لصالح الأطفال الذين يمثلون درجة فقدان سمعي لديه (• لع-9 7 ديسبل). 
تتفق هذه النتيجة مع دراسة (قنصوه، 9 ( ب ) والتي كان هدفها: فعالية برنامج الكتروني قائم على الأنشطة اللغويـة لتحسين اللغـة التعبيريـة والتواصل الاجتمـاعي لدى ضـعاف السمع،

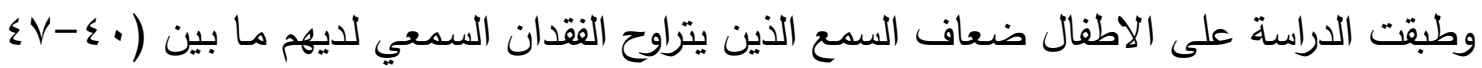
ديسبل)، واشـارت النتائج في هذه الدراسـة على وجود فروق ذات دلالــة احصـائية على افراد المجموعة التجريبية في الأداء القبلي والبعدي.



في ضوء ما توصلت إليه الدراسة يوصي الباحثان بما يلي:

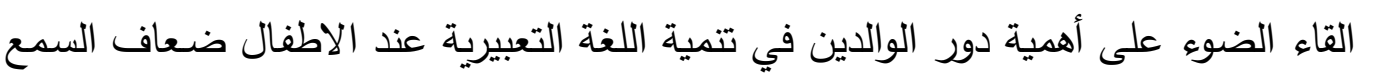
من خلال إقامة ورش مخصصة. تصـيم البرامج التدريبية اللازمـة للأطفال ضـعاف السمع؛ للتغلب على صـعبة اللغـة


تصميم برامج موجهاه للوالدين؛ للتعرف على المعوقات النفسية، والاجتماعية، والبيئية، والثقافية التي تؤثر على دورهم تجاه طفلهم ضعيف السمع وكيفية حل تلك المعوقات. ضرورة تفهم الوالدين خصائص طفلهم ضعيف السمع؛ للعمل على تتمية اللغة التعبيرية

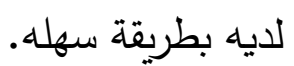
نشر الوعي في المجتمـع مـن خـلال وسـائل الإعـام المختلفة، والتأكيد على أهمية دور الوالدين تجاه الطفل ضعيف السمع. القيام بدورات تدريبية ارشادية لوالدي الطفل ضعيف السمع لتوعيتهم بأهمية دورهم تجاه طفلهم ضعيف السمع. 




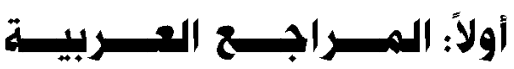

1- حسين، إيمان خيرو (0 1 • ب). فاعلية برنـامج تدرببي سمعي لفظي في اكتسـاب اللغة للى الأطفال زارعي العلزون في مرحلة الطفولة المبكرة (رسالة ماجستير، جامعة دمشق، سوريا). r- أبو الفضل، محفوظ عبد الستار (ب ( ب). فعالية برنامج إرشادي في تحسين النمو اللغوي لدى

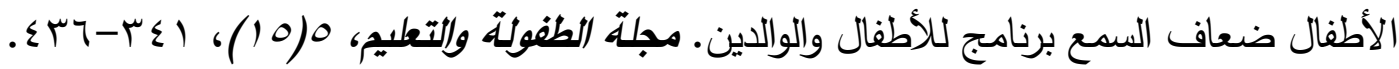

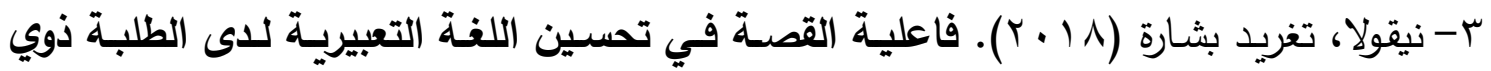
الإعاقة السمعية (رسالة ماجستير ، جامعة القدس، فلسطين). ع - عوض، سعيد حسين (T ا • Y). بناء برنامج في التلخل المبكر لتحسين المهارات اللغوية لاى الأطفال فاقدي السمع وقياس فاعليته (رسالة دكتوراه، جامعة عمان العربية، الأردن).

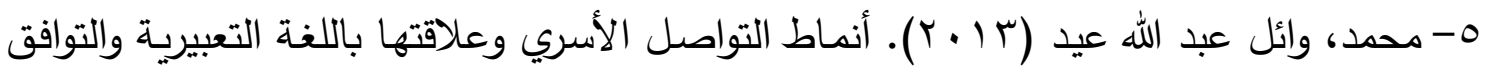

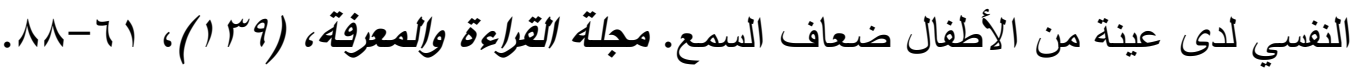
ד- حجازي، محمد أحمد (T ا • Y). دور الأسرة في التربية الاجتماعية. مركز الأبحاث والدراسات

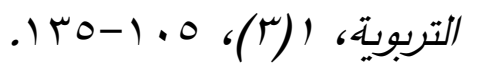

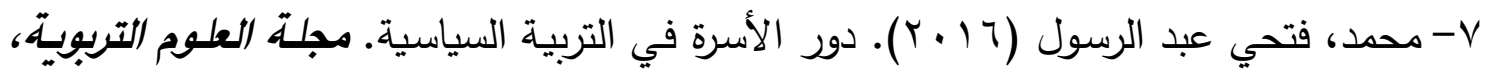

$$
.111-1 \cdot 1 \cdot(r y)
$$

1-زرارفة، فيروز مامي (ج ( • ب). التشئية الاجتماعية في الأسرة والمدرسة بين التطبع الاجتماعي

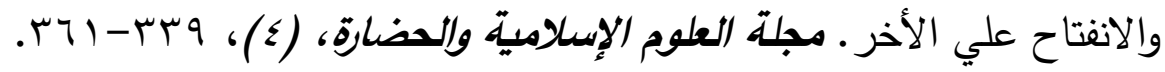
9- تواتي، نصيرة (9 ( • ب). تعليميـة اللغـة العربية لذوي الاحتياجـات الخاصـة فئسة الصـم البكم انموذجا (رسالة ماجستير، جامعة ابو بكر بلقايد، الجزائر).

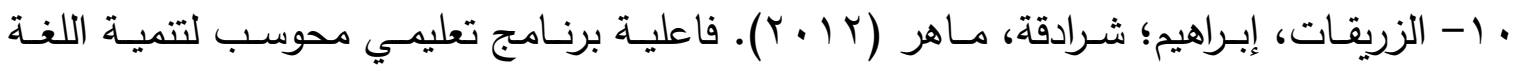
التعبيريـة لـى عينـة مـن الطلبـة ذوي الإعاقـة السـعية البسـيطة. دراسـات العلـوم التربوبـة، . o . ort 
ا ا - الفهيد، عبد الله سليمان (ع ( ب). فاعلية برنامج قائم علي القصة في تنمية مهارات التحدث

لاي تلاميذ الصف السادس الابتدائي (رسالة ماجستير، جامعة أم القرى، السعودية).

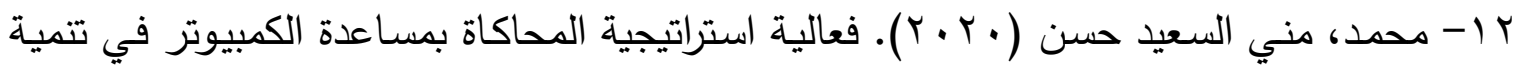
اللغة التعبيريـة لدي التلاميذ ذوي صسوبات التعليم. المجلـة العربيتة لعلـوم الإعاقـة والموهبتة.

$$
.1 \cdot \lambda-\lambda v \cdot(1)) \varepsilon
$$

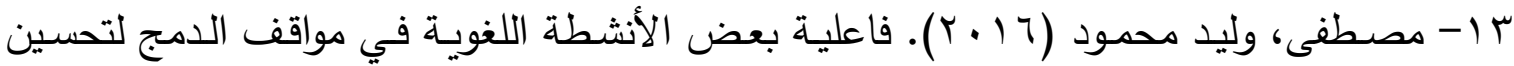

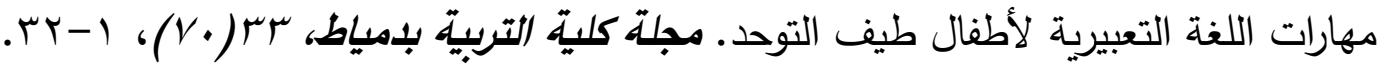
ع ا- سعدي، احمد (1 ا • ب). اللغة الوظيفية والمستويات التعبيريـة في النص القصصسي الجزائري.

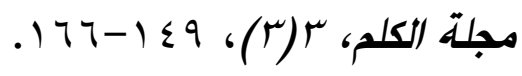

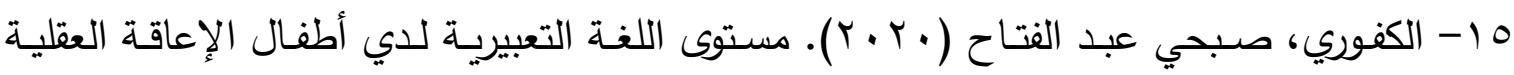

$$
\text { البسيطة، مجلة كلية التربية، ، ب (s). }
$$

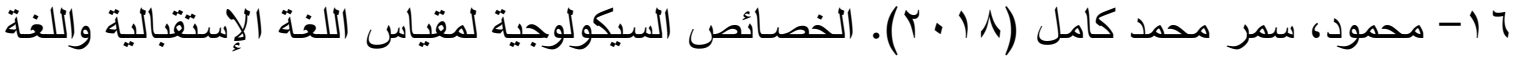

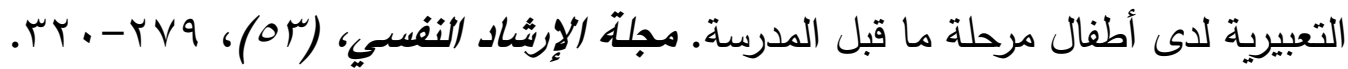

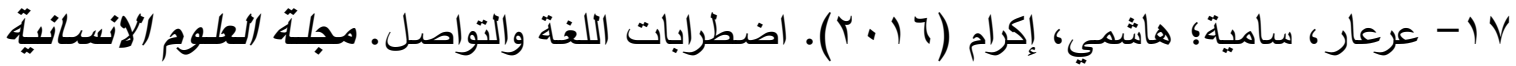

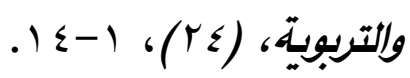

1 ا - السيد، سامي عبد السـلام (0 1 ب). فعالية برنـامج تدرببي لتخفيف بعض اضطرابات اللغة لاى عينة من الأطفال ضعاف السمع. (رسالة دكتوراة، جامعة بنها، مصر). 9 ا - صـالح، رنا عبد الحميد (ع ( • ؟). السـمات الثخصية لدى المـراهقين المعوقين سـعياً في ضوء بعض المتغيرات (رسالة ماجستير ، جامعة دمشق، سوريا). • ץ- عاشور ، حاتم؛ الشهراني، محمد (9 ( ـ ( ). المساندة الاجتماعية وعلاقتها بمفهوم الذات لدى

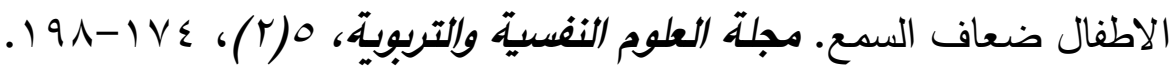

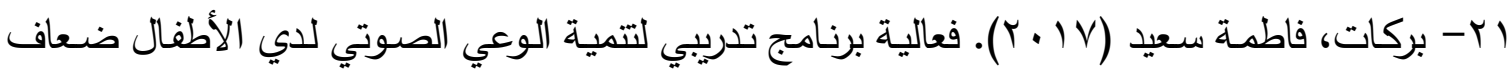

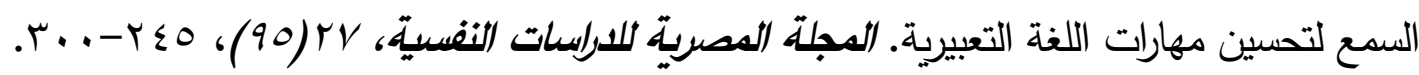


r r - محفوظ، عبد الرؤوف إسماعيل (10 • ( ). فاعلية برنامج تدريبي لتتمية مهارات التعبير الثفهي ومفهوم الذات الأكاديمي للدى مجموعـة مـن الأطفال ضـعاف السمع في مدينـة جدة. مجلـة

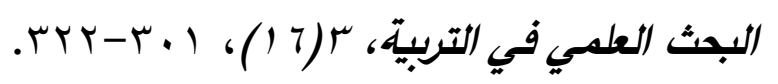

r - ابراهيم، فيوليت فؤاد (10 ( 1 ). الخصائص السيكو مترية لمقياس مفهوم الذات للتلاميذ ضعاف

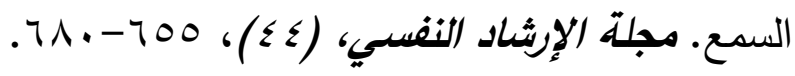

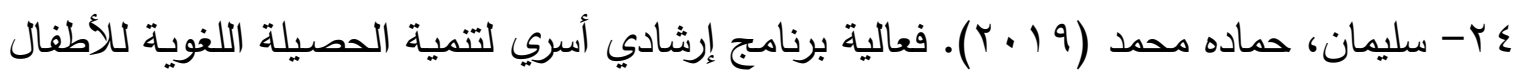
ضعاف السمع المعاقين عقلياً. مجلة كلية التربية، 9 ( (l)، V • r- דrس.

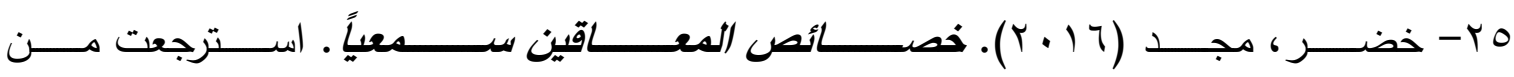
.https://cutt.us/qQpD2

ج - قنصوه، احمد السيد (9 ( • ( ). فعالية برنامج الكتروني قائم على الأنشطة اللغوية لتحسين اللغة التعبيرية والتواصل الاجتماعي لدى ضعاف السمع. المجلة العربية لعلوم الإعاقة والموهبة،

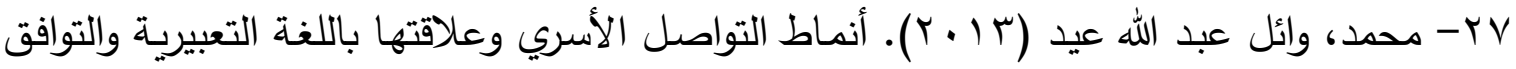

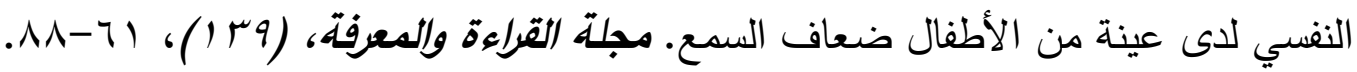

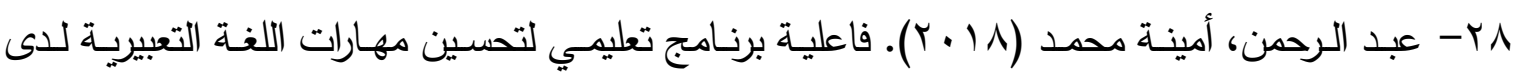

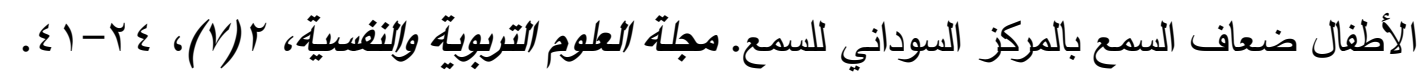

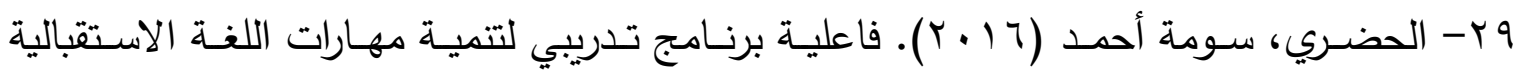
والتعبيريـة وتحسين فاعلية الذات للى عينـة الأطفال ضعاف السمع. مجلـة الإششـاد النفسـي،

$$
. r . r 00 \cdot(\leqslant 0)
$$

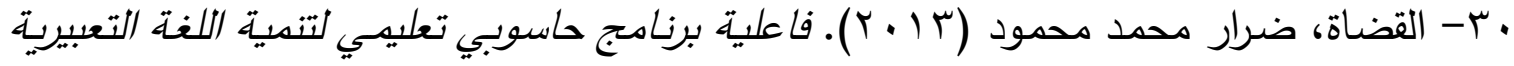
لدى عينتة من الطلبة ذوي الإعاقة السمعية البسبطة في الأردن. مجلـة البـث العلمسي فـي

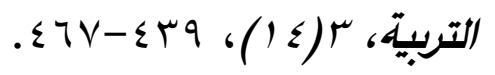




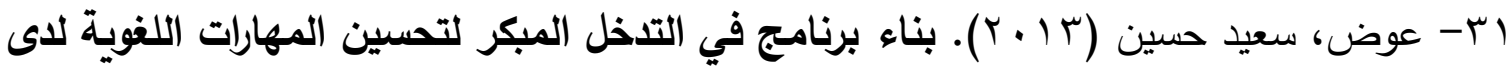

الأطفال فاقدي السمع وقياس فاعليته (رسالة دكتوراه، جامعة عمان العربية، الأردن).

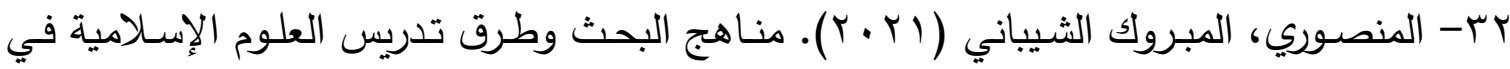

ضوء العلوم الإنسانية المعاصرة. مجلة جامعة المدينة العالمية المحكة،، (ro).

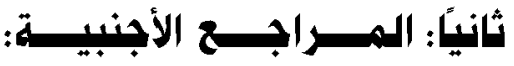

1- Bin Saddiq, L. (2021). Using an Electronic Educational Program Based on Orton-Gillingham Approach for Developing Expressive Language Skills of Hearing-Impaired Pupils at Integrated Schools in Saudi Arabia. European Online Journal of Natural and Social Sciences, 10(3), 309.

2- Hettiarachchi, S. (2020). The effectiveness of the adapted Box Clever language intervention program in the development of vocabulary and narrative skills of deaf and hard of hearing children. Deafness \& Education International, 1-27.

3- Caselli, N., Pyers, J., Lieberman, M. (2021). Deaf children of hearing parents have age-level vocabulary growth when exposed to American Sign Language by 6 months of age. The Journal of Pediatrics, (232), 229-236.

4- Davenport, C., Houston, D., Bowdrie, K., Frush, R. (2021). The Role of Early Intervention in Parental Self-Efficacy for Parents of Deaf and Hard-of-Hearing Children. Journal of Early Hearing Detection and Intervention, 6(1), 38-47.

5- Shangase, K. (2021). Continuity of Care at School for the HearingImpaired Child. Early Detection and Intervention in Audiology: An African perspective, 155. 


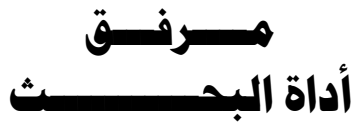

\begin{tabular}{|c|c|c|c|c|c|}
\hline \multirow[t]{2}{*}{$\begin{array}{l}\text { جامعة جدة } \\
\text { University of leddah }\end{array}$} & \multicolumn{5}{|c|}{ جامعة جلدة - كلية التربية } \\
\hline & & & & & بيانات عامهة: \\
\hline دراسات عليا & |بكالوريوس & دبلوه & ثانوية عامة & اقل من ثانوي & المستوى التعليمي \\
\hline \multicolumn{3}{|c|}{ انثى ( ) } & \multicolumn{2}{|c|}{ ذكر ( ) } & ضنس الطفل \\
\hline \multicolumn{3}{|c|}{ 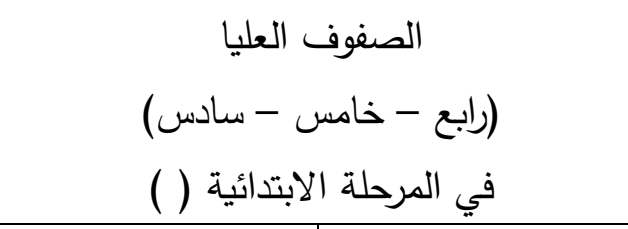 } & \multicolumn{2}{|c|}{ 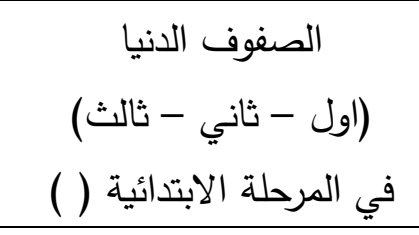 } & المرحلة الدراسية للطفل \\
\hline •V- • 9 ديسبل ( ) & \multicolumn{2}{|c|}{ • ع- • V ديسبل ( ) } & \multicolumn{2}{|c|}{ • ץ- • ع ديسبل ( ) } & للطفل ضرجة الفقدان السمعي \\
\hline
\end{tabular}




\begin{tabular}{|c|c|c|c|c|c|c|c|}
\hline غير مواقق & موافير & $\frac{1}{3}$ & $\frac{3}{9}$ & بشدة - مواقق & الفقــــــرات & & الأبعـــــاد \\
\hline & & & & & توفير الوالدين الوسائل والمعينات المساعدة للطفل & 1 & \multirow{7}{*}{ 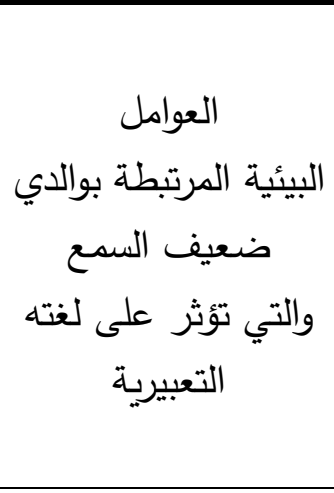 } \\
\hline & & & & & |تاحة الوالدين استخدام الأجهزة الححمولة للطفل & $r$ & \\
\hline & & & & & | انتقال الوالدين من بيئة لأخرى & $r$ & \\
\hline & & & & & |تأخر الوالدين تسجيل الطفل في المدرسة & $\varepsilon$ & \\
\hline & & & & & |سماح الوالدين للطفل مشاهدة التلفاز & 0 & \\
\hline & & & & & |تيسير الوالدين للطفل الألعاب الالكترونية & 7 & \\
\hline & & & & & سكن الوالدين مع الطفل في بيئة نائية & $\mathrm{V}$ & \\
\hline & & & & & |انشغال الوالدين الوظيفي عن الطفل & 1 & \multirow{4}{*}{ والاجتماعية المرتبطة } \\
\hline & & & & & |فاعلية الدخل المادي لوالدي الطفل & $r$ & \\
\hline & & & & & |دمج الوالدين الطفل مع اقرانه & $r$ & \\
\hline & & & & & سطوة الانطباعات الاجتماعية لدى والدي الطفل & $\varepsilon$ & \\
\hline & & & & & |الضغوطات النفسية لدى والدين الطفل & 1 & \multirow{6}{*}{ 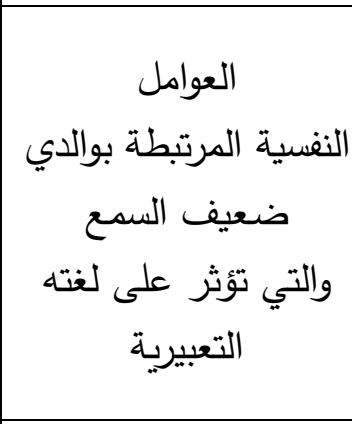 } \\
\hline & & & & & |علاقة الوالدين بالطفل & $r$ & \\
\hline & & & & & |الخلافات بين والدي الطفل & $r$ & \\
\hline & & & & & |اختلاف التتشئة بين والدي الطفل & $\varepsilon$ & \\
\hline & & & & & تعامل الوالدين الايجابي مع الطفل & 0 & \\
\hline & & & & & تشجيع الوالدين الطفل & 7 & \\
\hline & & & & & |وعي الوالدين بمفهوم اللغة التعبيرية للطفل & 1 & \multirow{9}{*}{ 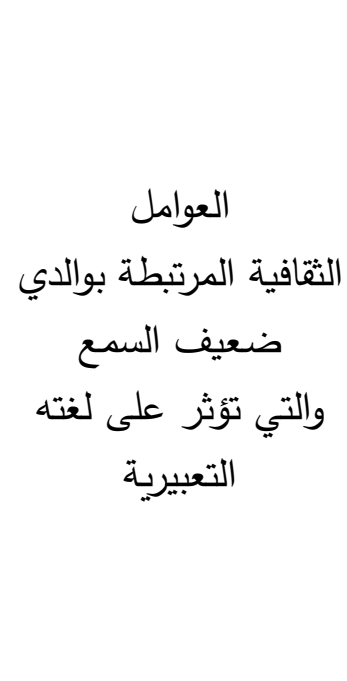 } \\
\hline & & & & & |ثقافة والدي الطفل & $r$ & \\
\hline & & & & & | اهتمام والدي الطفل بثقافته & $r$ & \\
\hline & & & & & مســاعدة الوالـدين الطفـل فـي انجـاز الواجبـات & $\varepsilon$ & \\
\hline & & & & & |المدرسية & & \\
\hline & & & & & |تحديث والدي الطفل بعدة لغات & 0 & \\
\hline & & & & & تدريب الوالدين الطفل على نطق الاصوات & 1 & \\
\hline & & & & & |وعي الوالدين بأساليب التتريب اللازمة للطفل & & \\
\hline & & & & & |الطبية للطفل الوالدين بكيفية التعامل مـع السماعة & & \\
\hline
\end{tabular}

